OPEN ACCESS

Edited by:

Loic Guillot,

Institut National de la Santé et de la

Recherche Médicale

(INSERM), France

Reviewed by:

Gill Diamond,

University of Louisville, United States

Michael F. Holick,

Boston Medical Center, United States

*Correspondence:

Jasmijn A. Schrumpf

j.a.schrumpf@/umc.nl

Specialty section:

This article was submitted to

Mucosal Immunity,

a section of the journal

Frontiers in Immunology

Received: 28 January 2020

Accepted: 03 June 2020

Published: 10 July 2020

Citation:

Schrumpf JA, van der Does AM and Hiemstra PS (2020) Impact of the Local Inflammatory Environment on Mucosal Vitamin D Metabolism and Signaling in Chronic Inflammatory Lung Diseases.

Front. Immunol. 11:1433.

doi: 10.3389/fimmu.2020.01433

\section{Impact of the Local Inflammatory Environment on Mucosal Vitamin D Metabolism and Signaling in Chronic Inflammatory Lung Diseases}

\author{
Jasmijn A. Schrumpf*, Anne M. van der Does and Pieter S. Hiemstra \\ Department of Pulmonology, Leiden University Medical Center, Leiden, Netherlands
}

Vitamin D plays an active role in the modulation of innate and adaptive immune responses as well as in the protection against respiratory pathogens. Evidence for this immunomodulatory and protective role is derived from observational studies showing an association between vitamin D deficiency, chronic airway diseases and respiratory infections, and is supported by a range of experimental studies using cell culture and animal models. Furthermore, recent intervention studies have now shown that vitamin $D$ supplementation reduces exacerbation rates in vitamin D-deficient patients with chronic obstructive pulmonary disease (COPD) or asthma and decreases the incidence of acute respiratory tract infections. The active vitamin $D$ metabolite, 1,25-dihydroxy-vitamin $D$ $\left(1,25(\mathrm{OH})_{2} \mathrm{D}\right)$, is known to contribute to the integrity of the mucosal barrier, promote killing of pathogens (via the induction of antimicrobial peptides), and to modulate inflammation and immune responses. These mechanisms may partly explain its protective role against infections and exacerbations in COPD and asthma patients. The respiratory mucosa is an important site of local $1,25(\mathrm{OH})_{2} \mathrm{D}$ synthesis, degradation and signaling, a process that can be affected by exposure to inflammatory mediators. As a consequence, mucosal inflammation and other disease-associated factors, as observed in e.g., COPD and asthma, may modulate the protective actions of $1,25(\mathrm{OH})_{2} \mathrm{D}$. Here, we discuss the potential consequences of various disease-associated processes such as inflammation and exposure to pathogens and inhaled toxicants on vitamin D metabolism and local responses to $1,25(\mathrm{OH})_{2} \mathrm{D}$ in both immune- and epithelial cells. We furthermore discuss potential consequences of disturbed local levels of $25(\mathrm{OH}) \mathrm{D}$ and $1,25(\mathrm{OH})_{2} \mathrm{D}$ for chronic lung diseases. Additional insight into the relationship between disease-associated mechanisms and local effects of $1,25(\mathrm{OH})_{2} \mathrm{D}$ is expected to contribute to the design of future strategies aimed at improving local levels of $1,25(\mathrm{OH})_{2} \mathrm{D}$ and signaling in chronic inflammatory lung diseases.

Keywords: inflammation, airway mucosa, vitamin D, vitamin D metabolism, host defense, COPD exacerbations 


\section{INTRODUCTION}

Vitamin D is a pleiotropic hormone that is well-known for its role in the regulation of calcium and phosphate homeostasis and bone mineralization. The vitamin D receptor (VDR) acts as the receptor for the active form of vitamin D, i.e., 1,25dihydroxy-vitamin $\mathrm{D}\left[1,25(\mathrm{OH})_{2} \mathrm{D}\right]$, and is expressed in nearly all tissues and cell-types and regulates a large number of genes $(\sim 0.8-5 \%$ of the total genome) $(1,2)$. As a result, vitamin D affects many additional processes including cell proliferation and differentiation, apoptosis, DNA repair, ion transport, metabolism, cell adhesion, and oxidative stress responses $(1,3)$. Vitamin D deficiency [serum 25-hydroxy-vitamin D [25(OH)D] $<50 \mathrm{nmol} / \mathrm{L} ; 25(\mathrm{OH}) \mathrm{D}$ is the main circulating form of vitamin $\mathrm{D}$ and its levels are used to assess vitamin $\mathrm{D}$ status in the clinic $(4,5)$ affects more than $30 \%$ of the children and adults worldwide and is a major cause of bone diseases such as rickets and osteoporosis (6). Increasing evidence has indicated that vitamin $\mathrm{D}$ deficiency is also associated with various other diseases such as cancer, cardiovascular disease, Alzheimer's disease and muscle myopathy, as well as several immune-related diseases such as type 1 diabetes, multiple sclerosis, inflammatory bowel disease (IBD), psoriasis and chronic inflammatory lung diseases including asthma, cystic fibrosis (CF), and chronic obstructive pulmonary disease (COPD) (6-9).

Several studies have now shown that vitamin D deficiency is prevalent in COPD patients and inversely correlated with lung function and severity of the disease (8-12). It is currently unknown whether vitamin $\mathrm{D}$ deficiency is a cause or consequence of COPD, since many COPD patients have low physical activity levels and spend most time indoors (13). There are however studies suggesting that low $25(\mathrm{OH}) \mathrm{D}$ levels are associated with development of COPD, based on observed associations between polymorphisms in the vitamin D binding protein (VDBP), $25(\mathrm{OH}) \mathrm{D}$ serum levels and COPD severity $(8,10,11,14)$. In addition, one study in mice showed that maternal vitamin D deficiency can impair lung -development, -structure and function in the offspring and suggests that even before birth, maternal $25(\mathrm{OH}) \mathrm{D}$ serum levels are important for a healthy lung development (15). This might be relevant, since associations have been found between lower childhood lung function and development of COPD later in life (16). The link between maternal 25(OH)D status and asthma development is however much clearer, since two recent randomized controlled trials (RCTs) have shown that maternal vitamin D supplementation reduces the risk of childhood asthma/recurrent wheeze (17). This might be explained by the fact that multiple vitamin D-regulated genes are transcriptionally active during alveolar maturation and a number of these genes are differentially expressed in asthma (18). Additionally, this protective effect was linked to the GGgenotype of the 17q21 functional SNP rs12936231, which is associated with lower expression of ORMDL3 and increased sphingolipid metabolism (19). Moreover, maternal circulating $25(\mathrm{OH}) \mathrm{D}$ levels affect the gut microbiota and can therefore indirectly modulate immune responses in the lung via the gutlung-axis (20). Also later in life, optimal 25(OH)D levels remain crucial for keeping the lungs healthy. For example, Heulens et al. showed that subacute and chronic cigarette smoke (CS) exposure decreased lung function and promoted early signs of emphysema and airway inflammation in vitamin D-deficient mice compared to vitamin D-sufficient animals (21). Similarly in an elastase-induced COPD mouse model, topical administration of vitamin $\mathrm{D}$ in the lungs counteracted alveolar damage and improved lung function (22). Yet in humans, it is still unclear whether vitamin D status influences COPD development and disease progression. Taken together, these observations suggest an important role for vitamin $\mathrm{D}$ during fetal and childhood lung maturation, and indicate that sufficient $25(\mathrm{OH}) \mathrm{D}$ levels might contribute to protection against development of childhood asthma and possibly COPD at older age.

Systemic levels of biologically active $1,25(\mathrm{OH})_{2} \mathrm{D}$ are tightly regulated to preserve sufficient levels of calcium $\left(\mathrm{Ca}^{2+}\right)$ and phosphate $\left(\mathrm{PO}_{4}{ }^{2-}\right)$ for optimal bone mineralization, whereas in mucosal tissues locally produced (autocrine) $1,25(\mathrm{OH})_{2} \mathrm{D}$ levels and signaling can be elevated or decreased upon exposure to inflammatory mediators, pathogens or inhaled toxicants (6). This could be important, since the inflamed airway mucosa of patients suffering from chronic inflammatory lung diseases is constantly exposed to these disease-associated factors $(8,23,24)$. Impaired local levels of $1,25(\mathrm{OH})_{2} \mathrm{D}$ and VDR signaling might have consequences for disease pathogenesis and progression. Dysregulated host defenses as found in patients with chronic inflammatory airway diseases include aberrant immune responses, altered microbiome composition, impaired epithelial barrier function, and aberrant secretion of host defense molecules (25-27). Adequate $1,25(\mathrm{OH})_{2} \mathrm{D}$ levels may provide protection against these dysregulated processes by maintaining the integrity of the mucosal barrier and promotion of killing of pathogens (e.g., via the induction of the antimicrobial peptide [AMP] hCAP18/LL-37) and via the modulation of both innate and adaptive immune responses $(7,28,29)$.

In this review, we first discuss the effects of these disease-associated factors on local synthesis and availability of $1,25(\mathrm{OH})_{2} \mathrm{D}$ and $1,25(\mathrm{OH})_{2} \mathrm{D}$-induced responses in the lung mucosa. In the second part of the review we will describe the mechanistic links between vitamin D deficiency and the pathogenesis of chronic inflammatory lung diseases such as asthma, CF and COPD, and discuss recent evidence related to the protective effects of vitamin D on COPD and on COPD exacerbations.

\section{MUCOSAL VITAMIN D METABOLISM IN HEALTH}

Vitamin D enters the circulation either via food intake (plantbased: vitamin $\mathrm{D}_{2}$ /animal-based: vitamin $\mathrm{D}_{3}$ ) or as a result of its synthesis in the skin by UVB radiation. It subsequently binds to the VDBP $(30,31)$, after which this complex is transported to the liver where it is converted by vitamin D-25hydroxylases (CYP2RI and CYP27A1) into 25(OH)D. However, recent studies showed that also other cell types such as airway epithelial cells, keratinocytes, intestinal epithelial cells, and monocytes/macrophages express CYP2RI and CYP27A1, and 
thus are able to (locally) convert vitamin $\mathrm{D}_{3}$ into $25(\mathrm{OH}) \mathrm{D}_{3}$ $(32,33)$. This inactive $25(\mathrm{OH}) \mathrm{D}$ needs to be converted into the active $1,25(\mathrm{OH})_{2} \mathrm{D}$ by 25 -hydroxyvitamin $\mathrm{D}$ - $1 \alpha$-hydroxylase (CYP27B1) in the kidney and in other cells, including several immune- and epithelial cells $(34-40) \cdot 1,25(\mathrm{OH})_{2} \mathrm{D}$ regulates expression of several genes by binding the nuclear VDR, which heterodimerizes with the retinoic acid receptor (RXR) to interact with vitamin D response elements (VDREs) that are present on the promoter region of these genes $(1,2)$. VDR is most abundantly expressed in intestinal enterocytes, pancreatic islets, renal distal tubules and osteoblasts, but is also present at lower levels in most other tissues and several other epithelial- and immune cells (41-45). Expression of VDR is classically regulated by $1,25(\mathrm{OH})_{2} \mathrm{D}$, growth factors and hormones such as FGF-23 and PTH, respectively, circulating calcium levels, bile acids, transcriptional co-activators/repressors, and genetic- and epigenetic modifications, which is tissue specific (46-49). 1,25(OH) 2 D regulates its own negative feedback by several mechanisms, including induction of expression of the catabolic enzymes 25-hydroxyvitamin D-24-hydroxylase (CYP24A1) and CYP3A4 $(50,51)$. CYP24A1 is expressed in most tissues and converts both $25(\mathrm{OH}) \mathrm{D}$ and $1,25(\mathrm{OH})_{2} \mathrm{D}$ into $23,25(\mathrm{OH})_{2} \mathrm{D}$ or $24,25(\mathrm{OH})_{2} \mathrm{D}$ and $1,23,25(\mathrm{OH})_{3} \mathrm{D}$ or $1,24,25(\mathrm{OH})_{3} \mathrm{D}$, respectively (dependent on whether CYP24A1 hydroxylates at $\mathrm{C}-23$ or at C-24). These are further converted into metabolites that have been found to be excreted into the bile (summarized in Figure 1) (50, 52, 56). CYP3A4 is mainly expressed in the liver and small intestines and contributes to the metabolic clearance of $25(\mathrm{OH}) \mathrm{D}$ and $1,25(\mathrm{OH})_{2} \mathrm{D}$ by converting $25(\mathrm{OH}) \mathrm{D}$ into $4 \beta, 25(\mathrm{OH})_{2} \mathrm{D}$, and $1,25(\mathrm{OH})_{2} \mathrm{D}$ into



FIGURE 1 | Vitamin D metabolism and expression of hCAP18/LL-37 (CAMP) in epithelial cells. The vitamin D binding protein (VDBP)-25(OH) $\mathrm{D}_{3}$ complex enters the epithelial cell from the circulation and $25(\mathrm{OH}) \mathrm{D}_{3}^{*}$ is subsequently released from the complex. In the cytoplasm, $25(\mathrm{OH}) \mathrm{D}_{3}$ is hydroxylated by $25-\mathrm{hydroxyvitamin}$ D-1 $\alpha$-hydroxylase (CYP27B1; localized to the inner mitochondrial membrane) into the active metabolite $1,25(\mathrm{OH})_{2} \mathrm{D}_{3} .1,25(\mathrm{OH})_{2} \mathrm{D}_{3}$ subsequently binds to the nuclear vitamin $\mathrm{D}$ receptor (VDR) which heterodimerizes with the retinoic acid receptor (RXR) to interact with vitamin $\mathrm{D}$ response elements (VDREs) that are present on the promoter region of numerous genes, including CAMP (hCAP18/LL-37) and CYP24A1 (25-hydroxyvitamin D-24-hydroxylase). 1,25(OH) $2 \mathrm{D}_{3}$ thereby regulates its own negative feedback via direct induction of CYP24A1 that hydroxylates both $25(\mathrm{OH}) \mathrm{D}_{3}$ and $1,25(\mathrm{OH})_{2} \mathrm{D}_{3}$ either at the $\mathrm{C}-23$ or at the $\mathrm{C}-24$ to $23,25(\mathrm{OH})_{2} \mathrm{D}_{3}$ or $24,25(\mathrm{OH})_{2} \mathrm{D}_{3}$ and $1,23,25(\mathrm{OH})_{3} \mathrm{D}_{3}$ or $1,24,25(\mathrm{OH})_{3} \mathrm{D}_{3}$, respectively. These metabolites are further converted by $\mathrm{CYP} 27 \mathrm{~B} 1$ [that first converts $24,25(\mathrm{OH})_{2} \mathrm{D}_{3}$ into $1,24,25(\mathrm{OH})_{3} \mathrm{D}_{3}$ ] and CYP24A1 into $25(\mathrm{OH}) \mathrm{D}_{3}-26,23$-lactone and 1,25(OH) $)_{2} \mathrm{D}_{3}-26,23$-lactone or into calcitroic acid, metabolites that are excreted in the bile $(50,52-55)$. ${ }^{*} T h e$ metabolism of $25(\mathrm{OH}) \mathrm{D}_{3}$ is shown in this figure, since there is more consensus regarding the metabolism of $25(\mathrm{OH}) \mathrm{D}_{3}$ and $1,25(\mathrm{OH}) 2 \mathrm{D}_{3}$ in literature. 
$1,23 \mathrm{R}, 25(\mathrm{OH})_{2} \mathrm{D}$ or $1,24 \mathrm{~S}, 25(\mathrm{OH})_{2} \mathrm{D}$ (51). Expression of both CYP27B1 and CYP24A1 in the kidneys is tightly regulated to maintain optimal $\mathrm{Ca}^{2+}$ - and $\mathrm{PO}_{4}{ }^{2-}$ levels in the circulation, which are important for bone mineralization (57). In short, in response to low $\mathrm{Ca}^{2+}$ levels, parathyroid hormone (PTH) is secreted by the pituitary glands, which in turn reduces $\mathrm{Ca}^{2+}$ excretion and reabsorption of $\mathrm{PO}_{4}{ }^{2-}$ (57). PTH further induces expression of CYP27B1 and represses expression of CYP24A1 in the kidneys (57). This will increase the levels of $1,25(\mathrm{OH})_{2} \mathrm{D}$ in the circulation, which promotes intestinal $\mathrm{Ca}^{2+}$ and $\mathrm{PO}_{4}{ }^{2-}$ absorption (57). These elevated circulating $\mathrm{Ca}^{2+}$ and $\mathrm{PO}_{4}{ }^{2-}$ levels will subsequently induce expression of fibroblast growth factor 23 (FGF-23) in osteocytes and osteoblasts and impair secretion of parathyroid hormone (PTH) by the parathyroid glands (3). In the kidneys, FGF23 suppresses expression of CYP27B1 and induces expression of CYP24A1, thereby inhibiting the synthesis and promoting degradation of $1,25(\mathrm{OH})_{2} \mathrm{D}(3)$. These complex mechanisms that explain how vitamin $\mathrm{D}$ and its metabolic enzymes maintain sufficient $\mathrm{Ca}^{2+}$ and $\mathrm{PO}_{4}{ }^{2-}$ levels in the circulation are more extensively discussed by Quarles et al. (57). In summary, it has become increasingly evident that the effects of vitamin $\mathrm{D}$ are not limited to homeostasis of $\mathrm{Ca}^{2+}$ and $\mathrm{PO}_{4}{ }^{2-}$ and bone mineralization, because several extra-renal cells such as airway epithelial cells and immune cells express the VDR and are capable of converting circulating $25(\mathrm{OH}) \mathrm{D}$ into the active $1,25(\mathrm{OH})_{2} \mathrm{D}$ metabolite.

\section{MUCOSAL VITAMIN D METABOLISM AND VITAMIN D SIGNALING IN CHRONIC INFLAMMATORY AIRWAY DISEASES}

Local levels and activity of $1,25(\mathrm{OH})_{2} \mathrm{D}$ are in part determined by expression of VDR and the equilibrium between the vitamin D metabolic enzymes CYP27B1 and CYP24A1. It is important to realize that mucosal expression of CYP24A1, CYP27B1 and also VDR can be affected by several disease-associated inflammatory mediators, toxicants and pathogens, summarized in Table 1. As a consequence of this, the local availability of $1,25(\mathrm{OH})_{2} \mathrm{D}$ and/or VDR signaling in tissues such as the inflamed airways of patients that suffer from chronic inflammatory airway diseases might be reduced.

\section{Epithelial Cells}

Chronic lung diseases are characterized by airway inflammation and impaired respiratory host defense, which is illustrated by the increased susceptibility for respiratory infections and exacerbations $(25,80,81)$. Furthermore, exposure to inhaled toxicants such as cigarette smoke and air pollutants are associated with disease pathogenesis and exacerbations in COPD, CF and in asthma patients (82-84). It would therefore be of great interest to investigate these effects on local $1,25(\mathrm{OH})_{2} \mathrm{D}$ levels and on $1,25(\mathrm{OH})_{2} \mathrm{D}$-mediated respiratory host defense in the airway mucosa. Studies in airway epithelial cells have shown that exposure to UV-inactivated non-typeable Haemophilus influenzae (NTHi) increased expression of the
TABLE 1 | Effects of inflammatory mediators on the expression of VDR, CYP24A1, and CYP27B1 in immune cells and epithelial cells.

\begin{tabular}{|c|c|c|c|}
\hline Cell/tissue type & Stimulus & Effect & References \\
\hline \multirow[t]{4}{*}{$\begin{array}{l}\text { Primary airway } \\
\text { epithelial cells }\end{array}$} & $\begin{array}{l}\text { Poly(I:C); RSV; IL-13; } \\
\text { IL-4; PM }\end{array}$ & CYP27B1 个 & $(38,58-60)$ \\
\hline & $\begin{array}{l}\text { TNF- } \alpha ; \text { IL-1 } \beta ; \text { IL-17A; } \\
\text { TGF- } \beta 1 ; \text { NTHi }\end{array}$ & CYP24A1 $\uparrow$ & $(61,62)$ \\
\hline & CSE & CYP27B1 $\downarrow$ & $(63,64)$ \\
\hline & $\begin{array}{l}\text { A. fumigatus; HRV; } \\
\text { RSV }\end{array}$ & VDR $\downarrow$ & $(58,65)$ \\
\hline \multirow{2}{*}{$\begin{array}{l}\text { BEAS-2B } \\
\text { (bronchial epithelial cell } \\
\text { line) }\end{array}$} & HRV; RSV & VDR $\downarrow$ & (58) \\
\hline & $\mathrm{PM}$ & $\operatorname{VDR} \uparrow$ & (59) \\
\hline \multirow{3}{*}{$\begin{array}{l}16 \mathrm{HBE} \\
\text { (bronchial epithelial cell } \\
\text { line) }\end{array}$} & A. fumigatus & $\operatorname{VDR} \uparrow$ & $(21)$ \\
\hline & TGF- $\beta 1$ & CYP27B1 $\uparrow$ & $(60)$ \\
\hline & A. fumigatus & CYP27B1 个 & $(21)$ \\
\hline $\begin{array}{l}\text { A549 } \\
\text { (lung carcinoma cell } \\
\text { line) }\end{array}$ & CSE & $\begin{array}{l}\text { VDR } \\
\text { translocation } \downarrow\end{array}$ & (66) \\
\hline \multirow{3}{*}{$\begin{array}{l}\text { HCT116 } \\
\text { (colon cancer epithelial } \\
\text { cell line) }\end{array}$} & LPS; TNF- $\alpha$ & CYP27B1 $\uparrow$ & $(67)$ \\
\hline & LPS; TNF- $\alpha$ & VDR $\downarrow$ & $(67,68)$ \\
\hline & LPS & CYP24A1 $\downarrow$ & $(67)$ \\
\hline $\begin{array}{l}\text { COGA-1A } \\
\text { (colon cancer epithelial } \\
\text { cell line) }\end{array}$ & TNF- $\alpha \pm I L-6$ & CYP27B1 $\downarrow$ & (69) \\
\hline \multirow[t]{2}{*}{ Trophoblasts } & TNF- $\alpha ; \mathrm{IL}-1 \beta ; \mathrm{IL}-6$ & CYP24A1 个 & (70) \\
\hline & $\mathrm{IFN}-\gamma$ & CYP27B1 $\uparrow$ & (70) \\
\hline Macrophages & ss-RNA & $\begin{array}{l}\text { CYP27B1 } \uparrow \\
\text { VDR } \uparrow\end{array}$ & $(71)$ \\
\hline $\begin{array}{l}\text { Macrophages } \\
\text { (derived from THP-1) }\end{array}$ & CSE & VDR $\uparrow$ & (72) \\
\hline $\begin{array}{l}\text { Macrophages } \\
\text { (derived from THP-1) }\end{array}$ & $\mathrm{BaP}$ & CYP24A1 个 & (73) \\
\hline \multirow[t]{2}{*}{ Monocytes } & $\begin{array}{l}\text { TLR2/1L } \pm \text { IFN- } \gamma ; \text { LPS; } \\
\text { IL-15 }\end{array}$ & $\begin{array}{l}\text { CYP27B1 } \uparrow \\
\text { VDR } \uparrow\end{array}$ & $(39,74-76)$ \\
\hline & IL-4 \pm TLR2/1L & CYP24A1 $\uparrow$ & (39) \\
\hline Neutrophils & $\begin{array}{l}\text { IFN- } \gamma \\
\text { S. pneumoniae T4R }\end{array}$ & $\begin{array}{l}\text { CYP27B1 } \uparrow \\
\text { VDR } \uparrow\end{array}$ & $(77)$ \\
\hline T cells & $\begin{array}{l}\text { T cell activators } \\
\text { (anti-CD3/anti-CD28; } \\
\text { PHA; PMA/ionomycin) }\end{array}$ & $\begin{array}{l}\text { CYP27B1 } \uparrow \\
\text { VDR } \uparrow\end{array}$ & (78) \\
\hline B cells & $\begin{array}{l}\text { B cell activators (anti- } \\
\text { IgM/anti-CD40/IL-21) }\end{array}$ & $\begin{array}{l}\text { CYP27B1 } \uparrow \\
\text { VDR } \uparrow\end{array}$ & (79) \\
\hline
\end{tabular}

Poly(l:C), Polyinosinic:polycytidylic acid; PM, Particulate matter; NTHi, nontypeable Haemophilus influenzae; A. fumigatus, Aspergillus fumigatus; CSE, Cigarette smoke extract; HRV, Human rhinovirus; RSV, Respiratory syncytial virus; sSRNA, Single stranded RNA; BaP, Benzo[a]pyrene; TLR2/1L, Toll like receptor 2/1 Ligand; PHA, Phytohemagglutinin; PMA, Phorbol 12-myristate 13-acetate.

catabolic enzyme CYP24A1, whereas exposure to viral double stranded-RNA analog polyinosinic:polycytidylic acid (Poly[I:C]) increased expression of CYP27B1 and thereby conversion of $25(\mathrm{OH}) \mathrm{D}$ into $1,25(\mathrm{OH})_{2} \mathrm{D}$, the active metabolite $(38,61)$. On the 
other hand, in the bronchial cell line BEAS-2B expression of VDR was decreased after infection with respiratory viruses such as human rhinovirus (HRV) and respiratory syncytial virus (RSV) (58). Collectively, these studies have shown in airway epithelial cells that respiratory viral- and bacterial infections can either promote or impair $1,25(\mathrm{OH})_{2} \mathrm{D}$ synthesis and responses.

A local airway inflammatory milieu can also exert differential effects on $1,25(\mathrm{OH})_{2} \mathrm{D}$ synthesis and signaling, dependent on the type of inflammatory mediators that are predominantly present. We have shown in differentiated primary airway epithelial cells that Th2 cytokines such as IL-4 and IL-13, enhance expression of CYP27B1 and expression of hCAP18/LL-37 upon $25(\mathrm{OH}) \mathrm{D} 3$ treatment, which suggests that a Th2-inflammatory environment, as found in allergic airway inflammation, increases the conversion of $25(\mathrm{OH}) \mathrm{D}$ into the active $1,25(\mathrm{OH})_{2} \mathrm{D}(83$, 85). The observation that levels of both $1,25(\mathrm{OH})_{2} \mathrm{D}$ and hCAP18/LL-37 were increased in bronchoalveolar lavage (BAL) after allergen challenge is in line with this proposed mechanism (86). This effect of Th2 cytokines was in contrast to the effects (chronic) exposures to the proinflammatory cytokines IL-1 $\beta$, TNF- $\alpha$ and IL-17A that strongly increased the expression of the $25(\mathrm{OH}) \mathrm{D}$ - and $1,25(\mathrm{OH})_{2} \mathrm{D}$-degrading CYP24A1, even in absence of its inducer $1,25(\mathrm{OH})_{2} \mathrm{D}$ (61). Furthermore, shortterm exposures to TGF- $\beta 1$, a pleiotropic growth factor which is elevated in the lungs of COPD, CF and asthma patients, also increases the expression of CYP24A1 (62). As a consequence, $1,25(\mathrm{OH})_{2} \mathrm{D}$-mediated expression of the AMP hCAP18/LL-37 was impaired, which was likely the result of the enhanced degradation of both $25(\mathrm{OH}) \mathrm{D}$ and $1,25(\mathrm{OH})_{2} \mathrm{D}$ by this enzyme $(61,62)$. In addition to pathogens and cytokines, exposure to inhaled toxicants such as cigarette smoke (CS) and particulate matter (PM) may also alter expression or activity of VDR and CYP27B1. Studies have demonstrated that cigarette smoking or exposure to CS extract (CSE) decreases expression of CYP27B1 and inhibited membrane bound (m)VDR translocation to the cell membrane in airway epithelial cells and A549 cells (an alveolar tumor cell line), respectively $(63,64,66)$. This inhibition reduces the conversion of $25(\mathrm{OH}) \mathrm{D}$ to $1,25(\mathrm{OH})_{2} \mathrm{D}$ and $1,25(\mathrm{OH})_{2} \mathrm{D}$-mediated gene expression as well as nongenomic actions of $1,25(\mathrm{OH})_{2} \mathrm{D}$-membrane associated, rapid response steroid-binding (MARRS)- signaling $(63,64,66)$. This adverse effect of cigarette smoking on the synthesis and effects of $1,25(\mathrm{OH})_{2} \mathrm{D}$ in airway epithelial cells was recently confirmed in vivo by Vargas Buonfiglio et al. who demonstrated that vitamin D supplementation increased antimicrobial activity in apical surface liquid (ASL) in the airway of healthy non-smokers, but not in smokers (64). On the other hand, exposure to PM increases the expression of both CYP27B1 and VDR in airway epithelial cells, thereby possibly promoting the synthesis and effects of $1,25(\mathrm{OH})_{2} \mathrm{D}(59)$. It is however important to consider that several retrospective and observational studies have demonstrated that air pollution is an independent risk factor for developing vitamin D deficiency (87). In conclusion, exposure to CS, TGF- $\beta 1$ and presence of a proinflammatory milieu appeared to most strongly decrease local presence and signaling of $1,25(\mathrm{OH})_{2} \mathrm{D}$ in airway epithelial cells.

\section{Immune Cells}

Whereas, various studies show that exposure to proinflammatory stimuli most likely affects local $25(\mathrm{OH}) \mathrm{D}$ and $1,25(\mathrm{OH})_{2} \mathrm{D}$ levels and reduces the effects of $25(\mathrm{OH}) \mathrm{D}$ and $1,25(\mathrm{OH})_{2} \mathrm{D}$ in (airway) epithelial cells, the opposite appears to be the case for immune cells. In monocytes, macrophages and neutrophils, effects on $1,25(\mathrm{OH})_{2} \mathrm{D}$ synthesis and antimicrobial responses upon $25(\mathrm{OH}) \mathrm{D}$ treatment were generally enhanced by these proinflammatory stimuli as illustrated by increased expression of both VDR and CYP27B1 $(39,71,74-77)$. It is therefore tempting to speculate that this apparent increase in antimicrobial responses upon 25(OH)D treatment in immune cells in an inflammatory environment may serve as a second line of defense and compensate for the enhanced epithelial degradation of $25(\mathrm{OH}) \mathrm{D}$ and $1,25(\mathrm{OH})_{2} \mathrm{D}$ during inflammation. Inhaled toxicants may also affect $1,25(\mathrm{OH})_{2} \mathrm{D}$ availability and responsiveness of immune cells. This is illustrated by two recent studies studying the effects of cigarette smoke on the human monocyte/macrophage-like cell line THP-1. One study showed that treatment with cigarette smoke extract (CSE) increased the expression of VDR without enhancing $1,25(\mathrm{OH})_{2} \mathrm{D}$ responses (72), while the other study -that focused on the effects of Benzo[a]pyrene (BaP) (a component produced by cigarette combustion)- demonstrated that $1,25(\mathrm{OH})_{2} \mathrm{D}$ mediated CYP24A1 expression was induced, which was found to further enhance degradation of $1,25(\mathrm{OH})_{2} \mathrm{D}(73)$. In summary, proinflammatory stimuli generally increased the effect of $25(\mathrm{OH}) \mathrm{D}$ and $1,25(\mathrm{OH})_{2} \mathrm{D}$ on immune cells, whereas more studies are needed to fully determine the impact of exposure to cigarette smoke and other inhaled toxicants.

\section{Lung Mucosa}

Whereas, these studies provide evidence that inflammation and inhaled toxicants may affect $25(\mathrm{OH}) \mathrm{D}$ and $1,25(\mathrm{OH})_{2} \mathrm{D}$ metabolism and responsiveness in epithelial cells and immune cells, it is not clear whether this has an impact on these events in lung tissue of patients with chronic lung diseases. Although evidence is limited, we can speculate that levels of $1,25(\mathrm{OH})_{2} \mathrm{D}$ and responses are also affected by disease-associated factors in mesenchymal cells that are present in the lung mucosa. One study that showed in a bleomycin fibrosis model and in primary lung mouse fibroblasts that TGF- $\beta 1$ reduced expression of the VDR might support this assumption (88). It is currently insufficiently studied whether exposures to disease-associated factors promote or impair levels of $1,25(\mathrm{OH})_{2} \mathrm{D}$ and responses in immune-, mesenchymal and epithelial cells combined to give a better reflection of the in vivo situation. Interestingly, one study did already show that nasal CYP27B1- and 1,25(OH $)_{2}$ D-levels are both reduced in chronic rhinosinusitis (CRS) patients with nasal polyps as compared to CRS-patients without nasal polyps, whereas no difference was found in circulating $1,25(\mathrm{OH})_{2} \mathrm{D}$ levels (89). Since most other studies were performed in vitro using monocultures of epithelial cells or immune cells, more complex models are needed to delineate this. Therefore, animal models or preferably more complex animal-free cell culture models using co-cultures or organs-on-chips models of primary fully differentiated epithelial cells, airway-derived fibroblasts or 
smooth muscle cells and immune cells could be considered in future studies.

\section{PROTECTIVE EFFECTS OF VITAMIN D ON MUCOSAL HOMEOSTASIS}

After discussing altered $25(\mathrm{OH}) \mathrm{D}$ and $1,25(\mathrm{OH})_{2} \mathrm{D}$ metabolism and responsiveness in the inflamed airway mucosa, it is important to consider the possible consequences of these inflammation-induced changes in the airway mucosa keeping in mind the pleotropic effects of $1,25(\mathrm{OH})_{2} \mathrm{D}$ that were introduced earlier. In several cells, tissues and organs, $1,25(\mathrm{OH})_{2} \mathrm{D}$ regulates multiple cellular processes that affect normal and malignant cell growth and differentiation $(90,91) \cdot 1,25(\mathrm{OH})_{2} \mathrm{D}$ displays furthermore protective effects on mucosal host defense by maintaining the integrity of the epithelial barrier, inhibition of epithelial-to-mesenchymal transition (EMT), stimulating production of AMPs and modulating both innate- and adaptive immune functions $(7,29,92)$. In addition, $1,25(\mathrm{OH})_{2} \mathrm{D}$ maintains both energetic and survival homeostasis in the mucosal epithelium through the modulation of stress and damage responses, including clearance of disturbing and stressful agents $(3,93)$ (Figure 2).

\section{Epithelial Barrier Function}

In chronic inflammatory lung diseases, epithelial barrier function is impaired, and as a consequence the susceptibility toward respiratory infections is increased (94). There is increasing evidence that $1,25(\mathrm{OH})_{2} \mathrm{D}$ promotes epithelial barrier integrity or protects against epithelial barrier destruction. In cells of the bronchial epithelial cell line $16 \mathrm{HBE}, 1,25(\mathrm{OH})_{2} \mathrm{D}$ inhibited CSEmediated reduction of the epithelial barrier and expression of

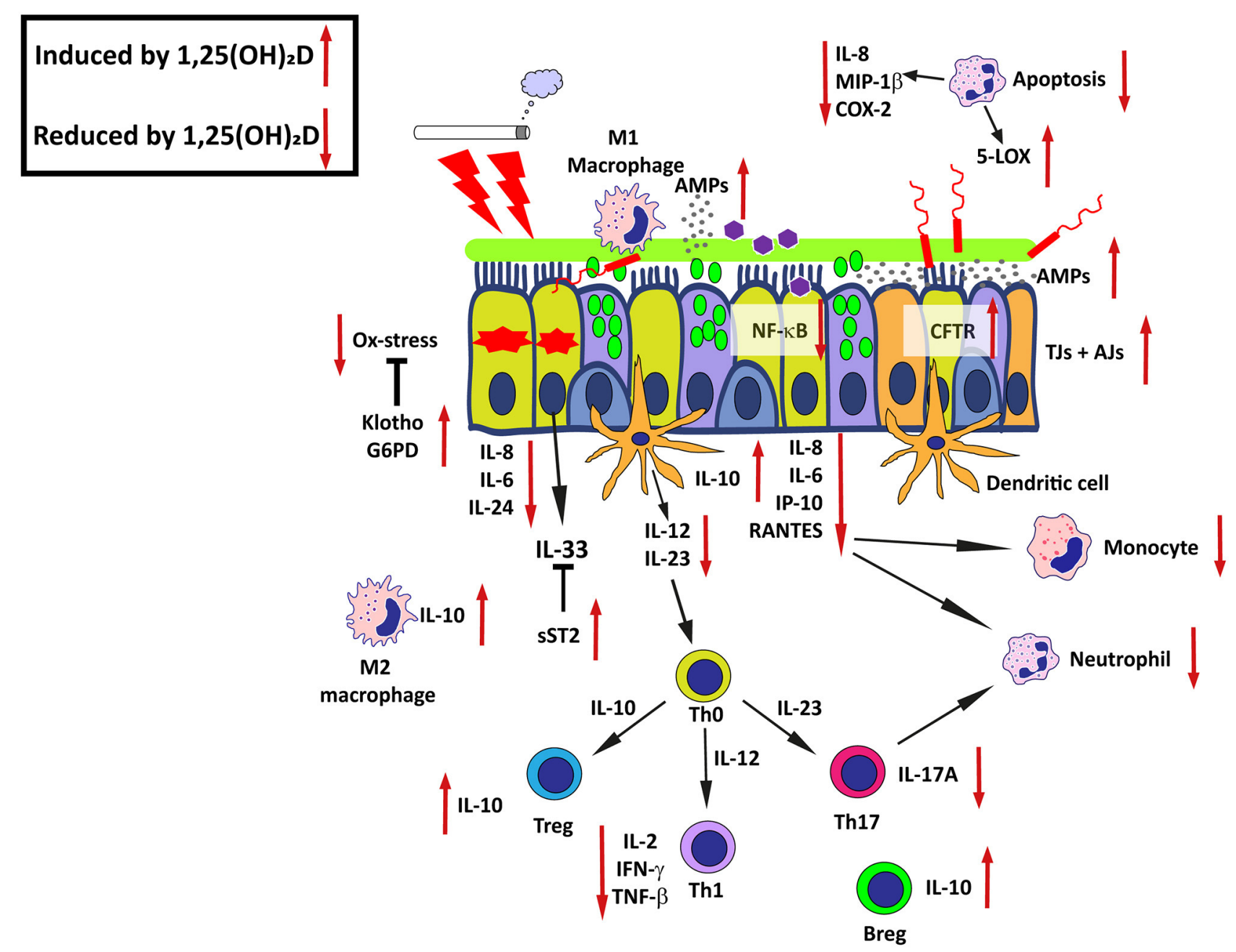

FIGURE 2 | Effects of active 1,25(OH $)_{2}$ D on airway epithelial host defense-mechanisms in chronic airway disease. The promoting or inhibitory effects of 1,25(OH $)_{2} \mathrm{D}$ are indicated by the red arrows. AMPs, Antimicrobial peptides; CFTR, Cystic fibrosis transmembrane conductance regulator; Ox-stress, Oxidative stress; SOCS, Suppressor of cytokine signaling proteins; TJs, Tight junctions; AJs, Adherens junctions; G6PD, Glucose-6-phosphate dehydrogenase; SST2, Soluble suppression of tumorigenicity 2; NF-kB, Nuclear factor kappa-light-chain-enhancer of activated B cells; Th0, Naieve T cell; Treg, Regulatory T cell; Th1, T helper type 1 cell; Th2, T helper type 2 cell; Th17, T helper type 17 cell; Breg, Regulatory B cell. See text for details and references. 
E-cadherin and $\beta$-catenin (95). Recently, two murine studies were published that investigated the effects of vitamin $\mathrm{D}$ on pulmonary epithelial barrier function. Shi et al. showed that vitamin D-supplementation alleviated lung injury in LPS-treated mice through maintenance of the pulmonary barrier by inducing expression of Zonula occludens (ZO)-1 and occludin in whole lung homogenates (96), whereas Gorman et al. showed in healthy mice, fed with a vitamin $\mathrm{D}$-poor diet, that vitamin $\mathrm{D}$ supplementation had little effect on epithelial integrity (97). Only the first study that used a more severe mouse model with higher levels of inflammation and edema found an effect of vitamin D on epithelial barrier function. Since inflammation is detrimental for epithelial barrier integrity (98), it cannot be excluded that the main protective effects of $1,25(\mathrm{OH})_{2} \mathrm{D}$ on the epithelial barrier in the first study by Shi et al. were in fact exerted through inhibition of inflammation rather than via direct induction of cell junction proteins. $1,25(\mathrm{OH})_{2} \mathrm{D}$ might also promote epithelial barrier function through its ability to increase expression of cystic fibrosis transmembrane conductance regulator (CFTR) in airway epithelial cells (32). CFTR maintains optimal ASL- and mucus hydration, volume and $\mathrm{pH}$ that support mucociliary clearance and activity of AMPs (99). Moreover, CFTR is also affected in the airways of smokers and COPD patients (100). In summary, these studies indicate that $1,25(\mathrm{OH})_{2} \mathrm{D}$ promotes both the integrity and function of the epithelial barrier and might additionally protect against epithelial damage by dampening inflammatory responses.

\section{Anti-fibrotic Effects of Vitamin D}

The loss of epithelial barrier function with a decrease in epithelial polarization and cell-junction proteins and a gain of expression of mesenchymal markers is a hallmark of EMT (94). EMT is primarily involved in development, wound healing and stem cell differentiation, and TGF- $\beta$ signaling plays a major role in this process (101). Elevated TGF- $\beta 1$ levels are found in the lungs of patients with chronic inflammatory lung diseases and this was associated with cigarette smoking, inflammation and fibrosis $(80,102)$. There are indications that $1,25(\mathrm{OH})_{2} \mathrm{D}$ counteracts various pathways leading to EMT. In mouse models and in airway epithelial cell lines, vitamin D supplementation and $1,25(\mathrm{OH})_{2} \mathrm{D}$, respectively, has been shown to inhibit EMT and fibrosis, in particular when this process is induced by TGF- $\beta 1(88,103-106)$.

\section{Effects of Vitamin D on Epithelial Antimicrobial Responses}

In addition to maintenance of the epithelial barrier and inhibition of fibrosis as discussed in the previous paragraphs, vitamin $\mathrm{D}$ is also actively involved in respiratory host defense by a variety of mechanisms $(3,29) .1,25(\mathrm{OH})_{2} \mathrm{D}$ is an important inducer of AMPs, which are mostly cationic peptides that have a broad-spectrum antimicrobial activity, the ability to modulate immune responses and to promote epithelial wound repair and angiogenesis (107). hCAP18/LL-37 is likely to be the most prominent AMP that is induced by $1,25(\mathrm{OH})_{2} \mathrm{D}$ and is expressed in several types of mucosal epithelial cells and immune cells such as monocytes and neutrophils $(38,77,108)$. In macrophages and intestinal epithelial cells, $1,25(\mathrm{OH})_{2} \mathrm{D}$ also increases expression of human $\beta$-defensin-2 (hBD-2), whereas in keratinocytes expression of both hBD-2 and human $\beta$-defensin3 (hBD-3) is increased by $1,25(\mathrm{OH})_{2} \mathrm{D}(109-112)$. Collectively these data show that AMPs are modulated by $1,25(\mathrm{OH})_{2} \mathrm{D}$ in mucosal tissues, which could have impact on susceptibility to both bacterial and viral infections and on the composition of the microbiota, which will be discussed in the next section.

\section{Effects of Vitamin D on Innate and Adaptive Immune Responses}

Diseases such as COPD and asthma are characterized by chronic inflammation, a low-grade and prolonged inflammation that may result in destruction and aberrant repair of surrounding tissue by growth factors, proteases and cytokines that are released at the site of inflammation (113-115). Cumulative data suggest that vitamin D exerts anti-inflammatory effects via its actions on both innate and adaptive immune responses. Upon viral infection or exposure of pro-inflammatory stimuli such as Poly(I:C) or $\mathrm{PM}, 1,25(\mathrm{OH})_{2} \mathrm{D}$ attenuates induced expression of cytokines and chemokines e.g., via inhibition of nuclear factor (NF)$\kappa \mathrm{B}$ or oxidative stress, respectively, in (airway) epithelial cells $(38,59,116)$. Furthermore, $1,25(\mathrm{OH})_{2} \mathrm{D}$ increases expression of the soluble decoy receptor for IL-33 (sST2) by airway epithelial cells, which in turn inhibits the actions of the type 2 alarmin IL-33 (117). Further effects of $1,25(\mathrm{OH})_{2} \mathrm{D}$ on local innate and adaptive immune responses in the epithelial mucosa are mediated through its actions on immune and structural cells and have been reviewed by Heulens et al. (29) Vanherwegen et al. (118), and Pfeffer et al. (119).

Taken together, these findings suggest that on the one hand $1,25(\mathrm{OH})_{2} \mathrm{D}$ protects against infections by enhancing epithelial barrier function and production of AMPs, and on the other hand $1,25(\mathrm{OH})_{2} \mathrm{D}$ induces tolerance and dampens proinflammatory responses in various cell types of the airway mucosa. Thereby, $1,25(\mathrm{OH})_{2} \mathrm{D}$ may prevent exaggerated inflammatory responses and further damage to the mucosal tissue, qualities that are very relevant in the context of chronic inflammatory (lung) diseases (Figure 2).

\section{Effects of Vitamin D on Epithelial Oxidative Stress and Aging}

COPD is considered to be a disease of accelerated aging lungs, underscored by markers of aging being increased in these patients partly as a result of oxidative stress (120). Evidence that $1,25(\mathrm{OH})_{2} \mathrm{D}$ may protect epithelial cells from oxidative stress was provided by Pfeffer et al. who demonstrated that $1,25(\mathrm{OH})_{2} \mathrm{D}$ increased expression of the antioxidant gene G6PD in airway epithelial cells. Furthermore, $1,25(\mathrm{OH})_{2} \mathrm{D}$ increased the ratio of reduced to oxidized glutathione and decreased the formation of 8-isoprostane after exposure to PM (59). The induction of klotho by $1,25(\mathrm{OH})_{2} \mathrm{D}$ might be another $1,25(\mathrm{OH})_{2} \mathrm{D}$-mediated anti-aging mechanism (121). Klotho is an anti-aging protein that is mainly expressed in the kidney, brain and in the lung by airway epithelial cells and exerts its protective effects through the inhibition of inflammation, insulin/IGF-1 signaling and activation of forkhead transcription factor (FoxO) signaling, which enables removal of reactive oxygen species 
(ROS) (122-124). Expression of klotho is impaired in the airways of smokers and further decreased in the airways of COPD patients and in cultures of the bronchial epithelial cell line $16 \mathrm{HBE}$ after CSE exposure (124). These studies suggest that $1,25(\mathrm{OH})_{2} \mathrm{D}$ may protect against aging via inhibition of oxidative stress and possibly via its ability to restore klotho expression (Figure 2). However, direct evidence showing that $1,25(\mathrm{OH})_{2} \mathrm{D}$ indeed increases expression of klotho in airway epithelial cells is currently lacking.

\section{Effects of Vitamin D on Epithelial Autophagy and Apoptosis}

In addition to providing protection against oxidative stress and aging, data from studies using intestinal epithelial cells suggest that $1,25(\mathrm{OH})_{2} \mathrm{D}$ may also promote cellular survival via the induction of autophagy and reduction of apoptosis $(125,126)$. In chronic inflammatory lung diseases, aberrant activation of autophagy plays a role in disease pathogenesis (127). A recent study showed that club cells and autophagy-related proteins were both decreased in COPD patients and that these proteins were important for club cell structure and function in airways (128). However, the effects of $1,25(\mathrm{OH})_{2} \mathrm{D}$ on autophagy in the airway mucosa of chronic inflammatory lung diseases are still unclear and need to be further evaluated (127).

\section{ROLE OF VITAMIN D IN THE TREATMENT OF CHRONIC AIRWAY DISEASES}

Clearly vitamin $\mathrm{D}$ has pivotal actions in host defense that are relevant in the context of chronic inflammatory lung diseases, in which vitamin D deficiency may be prevalent. Strategies to promote local levels of $1,25(\mathrm{OH})_{2} \mathrm{D}$ or use it as a treatment itself could be therefore of interest. Here, we will discuss the latest clinical evidence accompanied with functional in vitro and animal studies that may explain the effects of vitamin D supplementation on typical hallmarks of chronic airway diseases.

\section{Effect of Vitamin D on Inhaled Corticosteroid Responsiveness in Chronic Airway Diseases}

Currently, inhaled corticosteroid (ICS)-use with or without long acting bronchodilators is the most frequently used treatment for COPD and asthma patients ${ }^{1}$. However, the response to corticosteroids is not always effective in many COPD patients and in patients with steroid resistant (SR)-asthma (129). There are several complex mechanisms that underlie the resistance to corticosteroids in both COPD and SR-asthma that include but are not limited to genetic background, impaired glucocorticoid receptor binding, $\mathrm{T}$ helper type 17 cell (Th17)-inflammation and oxidative stress (e.g., from air pollution or smoking) and decreased numbers of IL-10 secreting regulator T cells (Tregs), which normally prevent skewing toward Th17-inflammation (129). Direct evidence of the ability of $1,25(\mathrm{OH})_{2} \mathrm{D}$ to reverse SR was provided by a study showing that ex-vivo stimulation

${ }^{1}$ https://goldcopd.org (2019). with $1,25(\mathrm{OH})_{2} \mathrm{D}$ promoted generation of IL-10-secreting Tregs which restored sensitivity toward corticosteroids in CD4+ T cells that were derived from SR-asthma patients (130). A further potential treatment role of $1,25(\mathrm{OH})_{2} \mathrm{D}$ was elegantly illustrated by studies that showed that vitamin $\mathrm{D}$ deficiency is associated with decreased steroid responsiveness in asthmatics and by the fact that several potential underlying mechanisms of SR such as oxidative stress and Th17-mediated inflammatory responses could be reversed by vitamin D treatment $(59,131-136)$. Interestingly, the corticosteroid dexamethasone was shown to increase expression of the $25(\mathrm{OH}) \mathrm{D}$ and $1,25(\mathrm{OH})_{2} \mathrm{D}$ degrading enzyme CYP24A1 in renal cells and osteoblasts (137), which suggests a bidirectional interaction between corticosteroids and $1,25(\mathrm{OH})_{2} \mathrm{D}$ and could further limit $1,25(\mathrm{OH})_{2} \mathrm{D}$ levels for patients. Additional research is needed to determine if vitamin D may also improve corticosteroid responsiveness in COPD.

\section{Vitamin D and Exacerbations in COPD}

Exacerbations are a major burden for COPD patients, they accelerate decline in lung function and frequently result into hospital admissions $(138,139)$. Exacerbations are often triggered by pollutants or by bacterial- and/or viral infections (82, 140, 141). COPD patients generally have lower serum $25(\mathrm{OH}) \mathrm{D}$ levels than age- and smoking-matched controls, which is associated with more and more severe exacerbations $(8,10)$. Several in vivo and in vitro studies have provided evidence that explain the protective effects of vitamin $\mathrm{D}$ on exacerbations in COPD patients and this will be discussed accordingly.

\section{Air Pollution}

First of all, Pfeffer et al. showed that 25(OH)D and 1,25(OH $)_{2} \mathrm{D}$ reduce the production of proinflammatory cytokines in part via the ability to enhance antioxidant responses in airway epithelial cells that were exposed to PM (59). This was also demonstrated in human DCs that were matured in presence of PM, where treatment with $1,25(\mathrm{OH})_{2} \mathrm{D}$ counteracted the expansion of proinflammatory IL- $17 \mathrm{~A}^{+}$and IFN- $\gamma^{+}$Th17.1 cells (134). In line with this, Bolcas et al., showed that vitamin D supplementation counteracted the development of airway hyperresponsiveness and accumulation of Th2/Th17 cells in mice that had been repeatedly exposed to both diesel exhaust and house dust mite allergens (142). Vitamin D could therefore exert a protective role in air pollution-triggered exacerbations.

\section{Respiratory Viral Infections}

In addition to its protective effects against pollutants, there is also increasing evidence that $1,25(\mathrm{OH})_{2} \mathrm{D}$ may enhance clearance of respiratory viral infections that account for $30-50 \%$ as underlying cause of exacerbations in COPD patients (143). Infections with respiratory viruses such as HRV, coronaviruses and to a lesser extend respiratory syncytial virus (RSV) and (para)influenza virus are present during exacerbations and may predispose the host toward secondary bacterial infections that can eventually lead to uncontrolled bacterial outgrowth, more severe exacerbations and neutrophilic inflammation $(143,144)$. Two recent in vitro studies showed that acute exposure to relatively high doses $(100-1000 \mathrm{nM})$ of $1,25(\mathrm{OH})_{2} \mathrm{D}$ reduced 
HRV-infection in undifferentiated cultures of airway epithelial cells $(58,145)$. In those models, $1,25(\mathrm{OH})_{2} \mathrm{D}$ most likely interfered with viral replication by increasing expression of interferon-stimulated genes and expression of hCAP18/LL-37, which has been shown to have direct antiviral activity (58, 145, 146). In fully differentiated airway epithelial cells, treatment with lower concentrations of $1,25(\mathrm{OH})_{2} \mathrm{D}(10 \mathrm{nM})$ during epithelial differentiation had no effect on acute HRV infection (147). As for other viruses than HRV, both Hansdottir et al. and Telcian et al. showed that $1,25(\mathrm{OH})_{2} \mathrm{D}$ did not decrease RSV infection in airway epithelial cells, but did reduce virus-induced inflammatory responses $(58,116)$. In addition, two other studies reported in influenza (H9N2 and H1N1)-infected A549 cells comparable findings $(148,149)$. Moreover, inhibitory effects of $1,25(\mathrm{OH})_{2} \mathrm{D}$ on poly(I:C)-induced inflammatory responses were furthermore confirmed in primary airway epithelial cells Hansdottir et al. and by our group $(38,85)$. Up to now, the afore mentioned studies suggest that higher doses of $1,25(\mathrm{OH})_{2} \mathrm{D}$ might be protective against HRV-infections in undifferentiated airway epithelial cells only, whereas for other respiratory viral infections $1,25(\mathrm{OH})_{2} \mathrm{D}$ mainly reduces inflammatory responses without affecting viral clearance. However, more studies are needed, especially in differentiated airway epithelial cells using multiple HRV-serotypes that use different receptors for infection to verify if $1,25(\mathrm{OH})_{2} \mathrm{D}$ indeed is capable of promoting HRVclearance. There is more consensus about $1,25(\mathrm{OH})_{2} \mathrm{D}$ reducing virus-induced inflammatory responses and this may certainly help to alleviate the burden of exacerbations in $\operatorname{COPD}(38,85)$.

\section{Bacterial Infections}

In addition to viral infections, also bacterial infections are associated with COPD exacerbations and account for $\sim 50 \%$ of all exacerbations (150). Due to improved study design and sampling techniques from the lower airways using bronchoscopy in recent decades, the causative role of bacteria in COPD-related exacerbations has become clear (150). This was additionally supported by Sethi et al., who found that acquisition of a new strain of pathogenic bacterial species into the airways was linked to COPD exacerbations (151). Recent developments in assessing the airway microbiota using $16 \mathrm{~S}$ rRNA sequencing techniques further demonstrated that during exacerbations, the relative abundance of Haemophilus, Pseudomonas, and Moraxella was increased and the microbial composition was shifted toward the Proteobacteria phylum (141). The ability of $1,25(\mathrm{OH})_{2} \mathrm{D}$ to promote antibacterial activity was recently demonstrated in cultures of airway epithelial cells. In differentiated airway epithelial cells, we have shown that both $25(\mathrm{OH}) \mathrm{D}$ and $1,25(\mathrm{OH})_{2} \mathrm{D}$ treatment enhances epithelial expression of hCAP18/LL-37 and antibacterial activity against NTHi, a Gram-negative bacterium, which is associated with COPD exacerbations $(61,152)$. In addition, Yim et al. demonstrated that $1,25(\mathrm{OH})_{2} \mathrm{D}$ treatment increased expression of the AMP hCAP18/LL-37 and killing of Pseudomonas aeruginosa and Bordetella bronchiseptica, which are both Gram-negative bacteria (153). These observed antibacterial effects of $1,25(\mathrm{OH})_{2} \mathrm{D}$ on airway epithelium in vitro were recently confirmed in vivo by Vargas Buonfiglio et al. The authors demonstrated that vitamin D supplementation increased antimicrobial activity against the Gram-positive Staphylococcus aureus in ASL in healthy non-smokers and was dependent on presence of hCAP18/LL-37 (64).

In murine airways, studies showed no effects of $1,25(\mathrm{OH})_{2} \mathrm{D}$ on the expression of Defb 4 or mCramp (the murine homolog for CAMP) (154). This can be explained by the fact that both the promotors of $m C r a m p$ and Defb 4 lack VDREs, suggesting that mice might not be suitable for studying the role of $1,25(\mathrm{OH})_{2} \mathrm{D}$ in AMP-mediated host defense in infection (155). Indeed, Niederstrasser et al. showed no effects of vitamin D deficiency on the susceptibility of mice to pulmonary infection with Streptococcus pneumoniae or Pseudomonas aeruginosa (156). However, in a recently developed mouse model by Lowry et al., who transfected $m$ Cramp knockout mice with the human $C A M P$ gene, topical vitamin $\mathrm{D}_{3}$ treatment increased expression of CAMP and promoted antibacterial effects on the mucosa of the skin (157). There are also multiple other murine studies that demonstrate protective effects of vitamin $\mathrm{D}$ on bacterial infections in the gut, indicating that $1,25(\mathrm{OH})_{2} \mathrm{D}-$ mediated antibacterial effects are additional modulated by other mechanisms such as via enhancement of epithelial barrier integrity $(67,158)$. In conclusion, these observations show that $1,25(\mathrm{OH})_{2} \mathrm{D}$ promotes protection against pollutants and enhances clearance of viral- and bacterial infections (both Gram-positive and negative bacteria) in combination with a dampening effect on exaggerated immune responses and these features might explain why vitamin $\mathrm{D}$ (deficiency) is linked to COPD exacerbations.

\section{Modulation of Microbiota by Vitamin D}

There are strong indications that modulation of immune responses and antibacterial activities by $1,25(\mathrm{OH})_{2} \mathrm{D}$ and/or $1,25(\mathrm{OH})_{2} \mathrm{D}$-regulated AMPs as well as autophagy have implications for the composition of the microbiota at the epithelial mucosa of the airways and the gut (159). Evidence for a role of AMPs in regulating the composition of the microbiota in the gut came from a variety of studies, including those showing that Paneth cell-derived defensins may modulate the composition of the microbiome (160). This notion is further supported by observations showing that many commensal gut bacteria are protected from killing by AMPs such as the $1,25(\mathrm{OH})_{2} \mathrm{D}$-inducible hCAP18/LL-37 and hBD-2, whereas pathogens are in general more sensitive (161). Alterations in the gut microbiota have been linked to many diseases of the gut such as IBD but also with diseases affecting the lungs such as COPD and asthma, implicating an important role for the so-called gut-lung axis $(162,163)$. The mechanisms that explain how gut microbiota affect lung health and disease are complex and include the production of short chain fatty acids (SCFAs). SCFA have a wide range of effects on both immune and structural cells, and the effect of SCFA produced in the intestine on lung immunity may in part be explained by modulation of myeloid cells in the bone marrow, which subsequently migrate to the airways and modulate local immune responses (163). Microbiota that are diverse, rich and contain a higher abundance of SCFAproducing species within these populations are considered to be 
associated with health (164). In the gut there is strong evidence that both vitamin $\mathrm{D}$ deficiency and/or supplementation affect composition of the adult and infant microbiota (164, 165), specifically in relation to disease (166). However, due to the limited number of RCTs and small sample sizes, the precise effects on the microbiota and the mechanisms involved in this are still unclear (164). Alterations in the lung microbiota are also observed in COPD and asthma patients and are likely the result of environmental exposures, airway remodeling, infections and treatments such as the use of antibiotics. This may contribute to disease pathogenesis through altered epithelial innate and adaptive immune responses that damages the airway epithelial barrier and provokes further changes in the lung microbiome that accumulates with increasing disease severity $(167,168)$. To date only 2 studies describe a possible influence of vitamin $\mathrm{D}$ on composition of the microbiota in the airways $(169,170)$. Toivonen et al. showed an association between low serum $25(\mathrm{OH}) \mathrm{D}$ levels and reduced richness of the nasopharyngeal microbiota and bronchiolitis severity in patients with low $25(\mathrm{OH}) \mathrm{D}$ levels (169), whereas in another study vitamin D supplementation decreased the abundance of Staphylococcus aureus, Staphylococcus epidermidis and Corynebacterium species in sputum samples in vitamin D-deficient CF patients compared to sufficient CF patients (170). In summary, there is evidence that alterations in the airway or gut microbiota can affect chronic airway disease and that these changes could be related to both vitamin $\mathrm{D}$ deficiency and/or supplementation. However, due to the limited number of RCTs and small sample sizes more RCTs are needed in larger patient populations.

\section{Effect of Vitamin D Supplementation on Chronic Airway Diseases COPD}

The above described protective and therapeutic possibilities of vitamin $\mathrm{D}$, together with observations that many COPD patients are vitamin $\mathrm{D}$ deficient, suggest that COPD patients might benefit from vitamin $\mathrm{D}$ supplementation. As discussed elsewhere in this review, the link between circulating 25(OH)D levels and the number of exacerbations has been extensively studied (8). So far however, only 4 RCTs have investigated the effect of vitamin D supplementation in the context of COPD: only 2 out of 4 RCTs showed that vitamin D supplementation reduces the number of exacerbations (171-174). However, in a post-hoc analysis, selecting those patients that were vitamin D deficient, exacerbations were indeed reduced after vitamin $\mathrm{D}$ supplementation. Jolliffe et al. summarized these 4 RCTs and performed a recent individual participant data meta-analysis and concluded that vitamin $\mathrm{D}$ supplementation is only protective against exacerbations in COPD patients with baseline serum $25(\mathrm{OH}) \mathrm{D}$ levels $<25 \mathrm{nmol} / \mathrm{L}$ (175). These important findings suggest that exacerbations in this specific subset of COPD patients are connected to vitamin D deficiency and this part can be resolved with supplementation. In summary, the protective effects of vitamin D in patients suffering from COPD are most prominent in those with vitamin $\mathrm{D}$ deficiency and this would indicate that serum levels $25(\mathrm{OH}) \mathrm{D}$ in these patients should always be determined before considering using vitamin $\mathrm{D}$ supplementation. Since only 4 RCTs with relatively small patient populations have been conducted in both vitamin D-sufficient and -deficient COPD patients, more RCTs are needed, especially in vitamin D-deficient patients. Currently, a multicenter RCT is being conducted by Rafiq et al. in a group of vitamin-deficient COPD patients $(25(\mathrm{OH}) \mathrm{D}<50 \mathrm{nmol} / \mathrm{L})$, which may reveal whether vitamin $\mathrm{D}$ supplementation is indeed protective against exacerbations in this group (176).

\section{Vitamin D Supplementation in Asthma, Cystic Fibrosis and Acute Respiratory Tract Infections}

In addition to the effects of vitamin $\mathrm{D}$ supplementation in COPD patients, the effects of vitamin D supplementation has also been extensively investigated in other lung diseases (which have associations with vitamin D deficiency) such as asthma, cystic fibrosis, upper respiratory tract infections. Most RCTs that investigated the effects of vitamin D supplementation were performed in acute respiratory tract infections (ARTIs) and asthma. A recent meta-analysis that assessed the effects of vitamin D supplementation in 25 RCTs (11,321 participants) showed that indeed vitamin D supplementation was protective against ATRIs and this effect was again more profound in patients with vitamin $\mathrm{D}$ deficiency $25(\mathrm{OH}) \mathrm{D}<25 \mathrm{nmol} / \mathrm{L}$ at baseline (177). A recent meta-analysis in asthma that included a total of 14 randomized controlled trials (1,421 participants), indicated that vitamin $\mathrm{D}$ supplementation reduced the rate of asthma exacerbations and increased lung function, especially in patients with vitamin $\mathrm{D}$ insufficiency $(25(\mathrm{OH}) \mathrm{D}<75 \mathrm{nmol} / \mathrm{L})$ (178). Interestingly, in asthma patients that were supplemented with vitamin $\mathrm{D}$, the frequency of respiratory infections was reduced, and this effect was related to the increase of hCAP18/LL-37 (179). CF patients with vitamin D deficiency had a higher rate of exacerbations as compared to patients with sufficient $25(\mathrm{OH}) \mathrm{D}$ levels (180). However, only one recent multicenter RCT was conducted and indicated that vitamin D supplementation did not affect the number of exacerbations in CF patients with serum 25(OH)D concentrations between 25 and $137.5 \mathrm{nmol} / \mathrm{L}$ (181). In summary, the protective effects of vitamin D supplementation in patients suffering from COPD, asthma or ARTIs are most prominent in those with vitamin $\mathrm{D}$ deficiency and this would indicate the importance of establishing serum levels $25(\mathrm{OH}) \mathrm{D}$ in these patients as supplementation could reduce unnecessary aggravated disease pathology as a result of this deficiency.

\section{CONCLUSION AND PERSPECTIVES}

Many drivers of COPD pathogenesis such as chronic exposure to noxious particles and gases, which are present in CS and air pollution, proteolytic enzymes, cytokines and chemokines that are released by infiltrating inflammatory cells, are known to harm the epithelial barrier and cause aberrant remodeling of the airway epithelium with important functional consequences for e.g., host defense. A dysfunctional epithelial barrier increases the susceptibility toward bacterial and viral infections, which are important triggers of COPD exacerbations and these exacerbations contribute importantly to disease 
progression. Sufficient local levels of $1,25(\mathrm{OH})_{2} \mathrm{D}$ may provide partial protection against these effects by reducing the effects of oxidative stress induced by exposure to inhaled oxidants or those derived from recruited inflammatory cells. $1,25(\mathrm{OH})_{2} \mathrm{D}$ furthermore protects against impairment of epithelial barrier function by promoting the integrity of the epithelial barrier, and by modulating both innate and adaptive immune responses. Protection against the detrimental effects of both bacterial and viral infections is provided by the ability of $1,25(\mathrm{OH})_{2} \mathrm{D}$ to promote of antiviral responses, induce expression of AMPs and modulate of inflammatory responses. Taken together, these activities suggest that $1,25(\mathrm{OH})_{2} \mathrm{D}$ may provide protection against development and progression of $\mathrm{COPD}$, and against disease exacerbations.

In addition, the local inflammatory milieu as well as the chronic exposure to noxious particles and gases, which are present in CS and air pollution, may negatively affect synthesis and signaling of $1,25(\mathrm{OH})_{2} \mathrm{D}$. Here we discussed recent in vitro studies that demonstrated that disease-associated factors such as inflammation and exposure to CS and air pollution could interfere with $1,25(\mathrm{OH})_{2} \mathrm{D}$ signaling and its degradation and activation by affecting expression of VDR, CYP24A1 and CYP27B1, respectively. These findings indicate that $1,25(\mathrm{OH})_{2} \mathrm{D}$ levels and its activities on airway mucosa might be impaired especially in patients with COPD with exposures to cigarette smoke and cytokines such as TNF- $\alpha$, IL-1 $\beta$, IL-17A and TGF$\beta 1$. This suggests that even in patients with sufficient $25(\mathrm{OH}) \mathrm{D}$ serum levels the local activity of $1,25(\mathrm{OH})_{2} \mathrm{D}$ in the lungs can be improved. We have to start generating more information on both systemic and local $1,25(\mathrm{OH})_{2} \mathrm{D}$ levels and gene expression signatures related to $25(\mathrm{OH}) \mathrm{D}$ and $1,25(\mathrm{OH})_{2} \mathrm{D}$ metabolism or responses in COPD (and other chronic inflammatory diseases that are related to vitamin $\mathrm{D}$ deficiency), both at baseline and after vitamin $\mathrm{D}$ supplementation. This information could lead to improved treatment strategies that enhance local efficacy

\section{REFERENCES}

1. Bouillon R, Carmeliet G, Verlinden L, van Etten E, Verstuyf A, Luderer HF, et al. Vitamin D and human health: lessons from vitamin D receptor null mice. Endocr. Rev. (2008) 29:726-76. doi: 10.1210/er.2008-0004

2. Wang TT, Tavera-Mendoza LE, Laperriere D, Libby E, Burton MacLeod $\mathrm{N}$, Nagai Y, et al. Large-scale in silico and microarray-based identification of direct 1,25-dihydroxyvitamin D3 target genes. Mol Endocrinol. (2005) 19:2685-95. doi: 10.1210/me.2005-0106

3. Christakos S, Dhawan P, Verstuyf A, Verlinden L, Carmeliet G. Vitamin D: metabolism, molecular mechanism of action, pleiotropic effects. Physiol Rev. (2016) 96:365-408. doi: 10.1152/physrev.00014.2015

4. Smith JE, Goodman DS. The turnover and transport of vitamin D and of a polar metabolite with the properties of 25-hydroxycholecalciferol in human plasma. J Clin Invest. (1971) 50:2159-67. doi: 10.1172/JCI106710

5. Holick MF, Binkley NC, Bischoff-Ferrari HA, Gordon CM, Hanley DA, Heaney RP, et al. Treatment, and prevention of Vitamin D deficiency: an endocrine society clinical practice guideline. J Clin Endocrinol Metab. (2011) 96:1911-30. doi: 10.1210/jc.2011-0385

6. Holick MF. The vitamin D deficiency pandemic: approaches for diagnosis, treatment and prevention. Rev Endocr Metab Disord. (2017) 18:153-65. doi: 10.1007/s11154-017-9424-1 of $1,25(\mathrm{OH})_{2} \mathrm{D}$, using e.g., specific CYP24A1-inhibitors such as VID400 (182). Alternatively, degradation by CYP24A1 could be prevented by using $1,25(\mathrm{OH})_{2} \mathrm{D}$ analogs that are insensitive to CYP24A1-mediated degradation, such as sulfone and sulfoximine derivatives, that also act as a VDR agonist (183). A third option is to entail the use of combination treatment with vitamin $\mathrm{D}$ and anti-inflammatory or certain anti-fibrotic drugs that target cytokines/proteins that are known to potentially decrease local levels and signaling of $1,25(\mathrm{OH})_{2} \mathrm{D}$ by inducing expression of CYP24A1 $(48,184,185)$. When considering such strategies, it should be noted that these may enhance the calcemic side effects and lead to unwanted inhibition of the immune system. We therefore need to carefully analyze the preclinical in vivo and in vitro studies and balance the pros and cons of the different strategies. In conclusion, future studies in COPD and but also in other chronic inflammatory diseases that are related to vitamin $\mathrm{D}$ deficiency, should be designed with more focus on assessing and improving local levels of $1,25(\mathrm{OH})_{2} \mathrm{D}$. These new insights may lead to the development of new treatment strategies, such as those targeting CYP24A1 to enhance local $1,25(\mathrm{OH})_{2} \mathrm{D}$ resulting in improved homeostasis and protection of the airway mucosa in patients with chronic inflammatory lung diseases.

\section{AUTHOR CONTRIBUTIONS}

JS, $\mathrm{AD}$, and PH: Conception and design. JS: Analyzing literature and drafting the manuscript. $\mathrm{AD}$ and $\mathrm{PH}$ : Revision of the manuscript. All authors: reviewed the manuscript and agree with its submission.

\section{FUNDING}

This study was supported by a grant from the Lung Foundation Netherlands (grant \#5.1.13.033) and a Marie Curie Global Fellowship (grant \#748569 -EpiCBiome).

7. Herr C, Greulich T, Koczulla RA, Meyer S, Zakharkina T, Branscheidt M, et al. The role of vitamin $\mathrm{D}$ in pulmonary disease: COPD, asthma, infection, and cancer. Respir Res. (2011) 12:31. doi: 10.1186/1465-9921-12-31

8. Zhu M, Wang T, Wang C, Ji Y. The association between vitamin D and COPD risk, severity, and exacerbation: an updated systematic review and meta-analysis. Int J Chronic Obstr Pulm Dis. (2016) 11:2597-607. doi: 10.2147/COPD.S101382

9. Brehm JM. Vitamin D and asthma-life after VIDA? Curr Allergy Asthma Rep. (2014) 14:461. doi: 10.1007/s11882-014-0461-5

10. Janssens W, Bouillon R, Claes B, Carremans C, Lehouck A, Buysschaert $\mathrm{I}$, et al. Vitamin D deficiency is highly prevalent in COPD and correlates with variants in the vitamin D-binding gene. Thorax. (2010) 65:215-20. doi: 10.1136/thx.2009.120659

11. Persson LJ, Aanerud M, Hiemstra PS, Hardie JA, Bakke PS, Eagan TM. Chronic obstructive pulmonary disease is associated with low levels of vitamin D. PLoS ONE. (2012) 7:e38934. doi: 10.1371/journal.pone.0038934

12. Burkes RM, Ceppe AS, Doerschuk CM, Couper D, Hoffman EA, Comellas AP, et al. Associations between 25-hydroxy-vitamin D levels, lung function, and exacerbation outcomes in COPD: an analysis of the SPIROMICS cohort. Chest. (2020) 157:856-65. doi: 10.1016/j.chest.2019.11.047

13. Kokturk N, Baha A, Oh YM, Young Ju J, Jones PW. Vitamin D deficiency: what does it mean for chronic obstructive pulmonary disease (COPD)? A 
compherensive review for pulmonologists. Clin Respir J. (2018) 12:382-97. doi: $10.1111 /$ crj. 12588

14. Persson LJ, Aanerud M, Hiemstra PS, Michelsen AE, Ueland T, Hardie JA, et al. Vitamin D, vitamin D binding protein, and longitudinal outcomes in COPD. PLoS ONE. (2015) 10:e0121622. doi: 10.1371/journal.pone.0121622

15. Zosky GR, Berry LJ, Elliot JG, James AL, Gorman S, Hart PH. Vitamin D deficiency causes deficits in lung function and alters lung structure. Am J Respir Crit Care Med. (2011) 183:1336-43. doi: 10.1164/rccm.201010-1596OC

16. Bui DS, Burgess JA, Lowe AJ, Perret JL, Lodge CJ, Bui M, et al. Childhood lung function predicts adult chronic obstructive pulmonary disease and asthma-chronic obstructive pulmonary disease overlap syndrome. Am J Respir Crit Care Med. (2017) 196:39-46. doi: 10.1164/rccm.201606-1272OC

17. Wolsk HM, Chawes BL, Litonjua AA, Hollis BW, Waage J, Stokholm $J$, et al. Prenatal vitamin D supplementation reduces risk of asthma/recurrent wheeze in early childhood: a combined analysis of two randomized controlled trials. PLoS ONE. (2017) 12:e0186657. doi: 10.1371/journal.pone.0186657

18. Kho AT, Sharma S, Qiu W, Gaedigk R, Klanderman B, Niu S, et al. Vitamin $\mathrm{D}$ related genes in lung development and asthma pathogenesis. BMC Med Genomics. (2013) 6:47. doi: 10.1186/1755-8794-6-47

19. Kelly RS, Chawes BL, Guo F, Zhang L, Blighe K, Litonjua AA, et al. The role of the $17 \mathrm{q} 21$ genotype in the prevention of early childhood asthma and recurrent wheeze by vitamin D. Eur Respir J. (2019) 54:1900761. doi: 10.1183/13993003.00761-2019

20. Sordillo JE, Zhou Y, McGeachie MJ, Ziniti J, Lange N, Laranjo N, et al. Factors influencing the infant gut microbiome at age 3-6 months: findings from the ethnically diverse Vitamin D Antenatal Asthma Reduction Trial (VDAART). J Allergy Clin Immunol. (2017) 139:482-91.e14. doi: 10.1016/j.jaci.2016.08.045

21. Heulens N, Korf H, Cielen N, De Smidt E, Maes K, Gysemans C, et al. Vitamin D deficiency exacerbates COPD-like characteristics in the lungs of cigarette smoke-exposed mice. Respir Res. (2015) 16:110. doi: 10.1186/s12931-015-0271-x

22. Horiguchi M, Hirokawa M, Abe K, Kumagai H, Yamashita C. Pulmonary administration of 1,25-dihydroxyvitamin D3 to the lungs induces alveolar regeneration in a mouse model of chronic obstructive pulmonary disease. $J$ Control Release. (2016) 233:191-7. doi: 10.1016/j.jconrel.2016.05.006

23. Limketkai BN, Mullin GE, Limsui D, Parian AM. Role of Vitamin D in inflammatory bowel disease. Nutr Clin Pract. (2017) 32:337-45. doi: $10.1177 / 0884533616674492$

24. Jolliffe DA, Greenberg L, Hooper RL, Griffiths CJ, Camargo CA, Kerley $\mathrm{CP}$, et al. Vitamin D supplementation to prevent asthma exacerbations: a systematic review and meta-analysis of individual participant data. Lancet RespirMed. (2017) 5:881-90. doi: 10.1016/S2213-2600(17)30306-5

25. V. De Rose, Molloy K, Gohy S, Pilette C, Greene CM. Airway epithelium dysfunction in cystic fibrosis and COPD. Med Inflam. (2018) 2018:20. doi: $10.1155 / 2018 / 1309746$

26. Martini E, Krug SM, Siegmund B, Neurath MF, Becker C. Mend your fences: the epithelial barrier and its relationship with mucosal immunity in inflammatory bowel disease. Cell Mol Gastroenterol Hepatol. (2017) 4:33-46. doi: 10.1016/j.jcmgh.2017.03.007

27. Heijink IH, Nawijn MC, Hackett TL. Airway epithelial barrier function regulates the pathogenesis of allergic asthma. Clin Exp Allergy. (2014) 44:620-30. doi: 10.1111/cea.12296

28. Colotta F, Jansson B, Bonelli F. Modulation of inflammatory and immune responses by vitamin D. J Autoimmun. (2017) 85:78-97. doi: 10.1016/j.jaut.2017.07.007

29. Heulens N, Korf H, Janssens W. Innate immune modulation in chronic obstructive pulmonary disease: moving closer toward vitamin D therapy. $J$ Pharmacol Exp Ther. (2015) 353:360-8. doi: 10.1124/jpet.115.223032

30. Reboul E. Intestinal absorption of vitamin D: from the meal to the enterocyte. Food Func. (2015) 6:356-62. doi: 10.1039/C4FO00579A

31. Holick MF. The cutaneous photosynthesis of previtamin D3: a unique photoendocrine system. J Invest Dermatol. (1981) 77:51-8, doi: 10.1111/1523-1747.ep12479237

32. DiFranco KM, Mulligan JK, Sumal AS, Diamond G. Induction of CFTR gene expression by $1,25(\mathrm{OH}) 2$ vitamin $\mathrm{D} 3,25 \mathrm{OH}$ vitamin D3, and vitamin D3 in cultured human airway epithelial cells and in mouse airways. J Steroid Biochem Mol Biol. (2017) 173:323-32. doi: 10.1016/j.jsbmb.2017.01.013
33. Vantieghem K, Overbergh L, Carmeliet G, De Haes P, Bouillon R, Segaert S. UVB-induced $1,25(\mathrm{OH}) 2 \mathrm{D} 3$ production and vitamin $\mathrm{D}$ activity in intestinal CaCo-2 cells and in THP-1 macrophages pretreated with a sterol Delta7reductase inhibitor. J Cell Biochem. (2006) 99:229-40. doi: 10.1002/jcb.20910

34. Adams JS, Clemens TL, Parrish JA, M.F. Holick Vitamin-D synthesis and metabolism after ultraviolet irradiation of normal and vitamin-D-deficient subjects. N Engl J Med. (1982) 306:722-5. doi: 10.1056/NEJM198203253061206

35. Stoffels K, Overbergh L, Giulietti A, Verlinden L, Bouillon R, Mathieu C. Immune regulation of 25-hydroxyvitamin-D3-1 $\alpha$-hydroxylase in human monocytes. J Bone Min Res. (2006) 21:37-47. doi: 10.1359/JBMR.0 50908

36. Zehnder D, Bland R, Williams MC, McNinch RW, Howie AJ, Stewart PM, et al. Extrarenal expression of 25-hydroxyvitamin D3-1 $\alpha$-hydroxylase1. $J$ Clin Endocrinol Metab. (2001) 86:888-94. doi: 10.1210/jcem.8 6.2.7220

37. Cross HS, Kállay E, Khorchide M, Lechner D. Regulation of extrarenal synthesis of 1,25-dihydroxyvitamin D3--relevance for colonic cancer prevention and therapy. Mol Aspects Med. (2003) 24:459-65. doi: 10.1016/S0098-2997(03)00041-4

38. Hansdottir S, Monick MM, Hinde SL, Lovan N, Look DC, Hunninghake GW. Respiratory epithelial cells convert inactive vitamin D to its active form: potential effects on host defense. J Immunol. (2008) 181:7090-9. doi: 10.4049/jimmunol.181.10.7090

39. Edfeldt K, Liu PT, Chun R, Fabri M, Schenk M, Wheelwright M, et al. T-cell cytokines differentially control human monocyte antimicrobial responses by regulating vitamin D metabolism. Proc Natl Acad Sci USA. (2010) 107:22593-8. doi: 10.1073/pnas.1011624108

40. Pillai S, Bikle DD, Elias PM. 1, 25-dihydroxyvitamin D production and receptor binding in human keratinocytes varies with differentiation. J Biol Chem. (1988) 263:5390-5.

41. Wang Y, Zhu J, DeLuca HF. Where is the vitamin D receptor? Arch Biochem Biophys. (2012) 523:123-33. doi: 10.1016/j.abb.2012.04.001

42. Boland RL. VDR activation of intracellular signaling pathways in skeletal muscle. Mol Cell Endocrinol. (2011) 347:11-6. doi: 10.1016/j.mce.2011.05.021

43. O'Connell TD, Simpson RU. Immunochemical identification of the 1,25dihydroxyvitamin D3 receptor protein in human heart. Cell Biol Int. (1996) 20:621-4. doi: 10.1006/cbir.1996.0081

44. Chen S, Glenn DJ, Ni W, Grigsby CL, Olsen K, Nishimoto $\mathrm{M}$, et al. Expression of the Vitamin D receptor is increased in the hypertrophic heart. Hypertension. (2008) 52:1106-12. doi: 10.1161/HYPERTENSIONAHA.108.119602

45. Gascon-Barré M, Demers C, Mirshahi A, Néron S, Zalzal S, Nanci A. The normal liver harbors the vitamin D nuclear receptor in nonparenchymal and biliary epithelial cells. Hepatology. (2003) 37:1034-42. doi: 10.1053/jhep.2003.50176

46. Saccone D, Asani F, Bornman L. Regulation of the vitamin D receptor gene by environment, genetics and epigenetics. Gene. (2015) 561:171-80. doi: 10.1016/j.gene.2015.02.024

47. Lee SM, Meyer MB, Benkusky NA, O'Brien CA, Pike JW. The impact of VDR expression and regulation in vivo. J Steroid Biochem Mol Biol. (2017) 177:36-45. doi: 10.1016/j.jsbmb.2017.06.002

48. Solomon JD, Heitzer MD, Liu TT, Beumer JH, Parise RA, Normolle DP, et al. VDR activity is differentially affected by Hic-5 in prostate cancer and stromal cells. Mol Cancer Res. (2014) 12:1166-80. doi: 10.1158/1541-7786.MCR-13-0395

49. Makishima M, Lu TT, Xie W, Whitfield GK, Domoto H, Evans RM, et al. Vitamin D receptor as an intestinal bile acid sensor. Science. (2002) 296:1313-6. doi: 10.1126/science.1070477

50. Jones G, Prosser DE, Kaufmann M. 25-Hydroxyvitamin D-24-hydroxylase (CYP24A1): Its important role in the degradation of vitamin D. Arch Biochem Biophys. (2012) 523:9-18. doi: 10.1016/j.abb.2011.11.003

51. Wang Z, Schuetz EG, Xu Y, Thummel KE. Interplay between vitamin D and the drug metabolizing enzyme CYP3A4. J Steroid Biochem Mol Biol. (2013) 136:54-8. doi: 10.1016/j.jsbmb.2012.09.012

52. Sakaki T, Sawada N, Komai K, Shiozawa S, Yamada S, Yamamoto $\mathrm{K}$, et al. Dual metabolic pathway of 25-hydroxyvitamin D3 catalyzed by human CYP24. Eur J Biochem. (2000) 267:6158-65. doi: 10.1046/j.1432-1327.2000.01680.x 
53. Jones G, Strugnell SA, DeLuca HF. Current understanding of the molecular actions of vitamin D. Physiol Rev. (1998) 78:1193-231. doi: 10.1152/physrev.1998.78.4.1193

54. Veldurthy V, Wei R, Campbell M, Lupicki K, Dhawan P, Christakos S. Chapter six - 25-Hydroxyvitamin D3 24-Hydroxylase: a key regulator of 1,25(OH)2D3 catabolism and calcium homeostasis. In Litwack G, editor, Vitamins \& Hormones, (Academic Press) (2016). p. 137-150. doi: 10.1016/bs.vh.2015.10.005

55. Ishizuka S, Norman AW. Metabolic pathways from 1 alpha,25dihydroxyvitamin D3 to 1 alpha,25-dihydroxyvitamin D3-26,23-lactone. Stereo-retained and stereo-selective lactonization. $J$ Biol Chem. (1987) 262:7165-70.

56. Zimmerman DR, Reinhardt TA, Kremer R, Beitz DC, Reddy GS, Horst RL. Calcitroic acid is a major catabolic metabolite in the metabolism of 1 $\alpha$-dihydroxyvitamin D2. Arch Biochem Biophys. (2001) 392:14-22. doi: 10.1006/abbi.2001.2419

57. Quarles LD. Endocrine functions of bone in mineral metabolism regulation. J Clin Invest. (2008) 118:3820-28. doi: 10.1172/JCI36479

58. Telcian AG, Zdrenghea MT, Edwards MR, Laza-Stanca V, Mallia P, Johnston SL, et al. Vitamin D increases the antiviral activity of bronchial epithelial cells in vitro. Antiviral Res. (2017) 137:93-101. doi: 10.1016/j.antiviral.2016.11.004

59. Pfeffer PE, Lu H, Mann EH, Chen Y-H, Ho T-R, Cousins DJ, et al. Effects of vitamin $\mathrm{D}$ on inflammatory and oxidative stress responses of human bronchial epithelial cells exposed to particulate matter. PLoS ONE. (2018) 13:e0200040. doi: 10.1371/journal.pone.0200040

60. Wang J, Liu X, Wang H, Li Y, Lan N, Yuan X, et al. Allergen specific immunotherapy enhanced defense against bacteria via TGF$\beta 1$-induced CYP27B1 in asthma. Oncotarget. (2017) 8:68681-95. doi: 10.18632 /oncotarget.19826

61. Schrumpf JA, Amatngalim GD, Veldkamp JB, Verhoosel RM, Ninaber DK, Ordonez SR, et al. Proinflammatory cytokines impair vitamin D-induced host defense in cultured airway epithelial cells. Am. J. Resp. Cell Mol Biol. (2017) 56:749-61. doi: 10.1165/rcmb.2016-0289OC

62. Schrumpf JA, Ninaber DK, A.M. van der Does, Hiemstra PS. TGF-beta1 impairs vitamin D-induced and constitutive airway epithelial host defense mechanisms. J Innate Immun. (2020) 12:74-89. doi: 10.1159/000497415

63. Mulligan JK, Nagel W, O'Connell BP, Wentzel J, Atkinson C, Schlosser RJ. Cigarette smoke exposure is associated with vitamin D3 deficiencies in patients with chronic rhinosinusitis. J Allergy Clin Immunol. (2014) 134:342-9.e1. doi: 10.1016/j.jaci.2014.01.039

64. Vargas Buonfiglio LG, Cano M, Pezzulo AA, Vanegas Calderon OG, Zabner J, Gerke AK, et al. Effect of vitamin $\mathrm{D}(3)$ on the antimicrobial activity of human airway surface liquid: preliminary results of a randomised placebocontrolled double-blind trial. BMJ Open Respir Res. (2017) 4:e000211. doi: 10.1136/bmjresp-2017-000211

65. Coughlan CA, Chotirmall SH, Renwick J, Hassan T, Low TB, Bergsson G, et al. The effect of aspergillus fumigatus infection on vitamin $\mathrm{D}$ receptor expression in cystic fibrosis. Am J Respir Crit Care Med. (2012) 186:999-1007. doi: 10.1164/rccm.201203-0478OC

66. Uh ST, Koo SM, Kim YK, Kim KU, Park SW, Jang AS, et al. Inhibition of vitamin d receptor translocation by cigarette smoking extracts. Tubercul. Respir Dis. (2012) 73:258-65. doi: 10.4046/trd.2012.73.5.258

67. Du J, Wei X, Ge X, Chen Y, Li YC. Microbiota-dependent induction of colonic Cyp27b1 Is associated with colonic inflammation: implications of locally produced 1,25-dihydroxyvitamin D3 in inflammatory regulation in the colon. Endocrinology. (2017) 158:4064. doi: 10.1210/en.2017-00578

68. Bakke D, Sun J. Ancient nuclear receptor VDR with new functions: microbiome and inflammation. Inflam Bowel Dis. (2018) 24:1149-54. doi: 10.1093/ibd/izy092

69. Hummel DM, Fetahu IS, Gröschel C, Manhardt T, Kállay E. Role of proinflammatory cytokines on expression of vitamin D metabolism and target genes in colon cancer cells. J Steroid Biochem Mol Biol. (2014) 144:915. doi: 10.1016/j.jsbmb.2013.09.017

70. Noyola-Martínez N, Díaz L, Zaga-Clavellina V, Avila E, Halhali A, Larrea F, et al. Regulation of CYP27B1 and CYP24A1 gene expression by recombinant pro-inflammatory cytokines in cultured human trophoblasts.
J Steroid Biochem Mol Biol. (2014) 144:106-9. doi: 10.1016/j.jsbmb.201 3.12.007

71. Campbell GR, Spector SA. Toll-like receptor 8 ligands activate a vitamin D mediated autophagic response that inhibits human immunodeficiency virus type 1. PLoS Pathog. (2012) 8:e1003017. doi: 10.1371/journal.ppat.1003017

72. Heulens N, Korf H, Mathyssen C, Everaerts S, De Smidt E, Dooms C, et al. 1,25-dihydroxyvitamin D modulates antibacterial and inflammatory response in human cigarette smoke-exposed macrophages. PLoS ONE. (2016) 11:e0160482. doi: 10.1371/journal.pone.0160482

73. Matsunawa M, Amano $Y$, Endo K, Uno S, Sakaki T, Yamada S, et al. The aryl hydrocarbon receptor activator benzo[a]pyrene enhances vitamin d3 catabolism in macrophages. Toxicolog Sci. (2009) 109:50-8. doi: 10.1093/toxsci/kfp044

74. Liu PT, Stenger S, Li H, Wenzel L, Tan BH, Krutzik SR, et al. Toll-Like receptor triggering of a vitamin d-mediated human antimicrobial response. Science. (2006) 311:1770-3. doi: 10.1126/science.1123933

75. Adams JS, Ren S, Liu PT, Chun RF, Lagishetty V, Gombart AF, et al. Vitamin d-directed rheostatic regulation of monocyte antibacterial responses. $J$ Immunol. (2009) 182:4289-95. doi: 10.4049/jimmunol.0803736

76. Krutzik SR, Hewison M, Liu PT, Robles JA, Stenger S, Adams JS, et al. IL-15 links TLR2/1-induced macrophage differentiation to the vitamin D-dependent antimicrobial pathway. J Immunol. (2008) 181:7115-20. doi: 10.4049/jimmunol.181.10.7115

77. Subramanian K, Bergman P, Henriques-Normark B. Vitamin D promotes pneumococcal killing and modulates inflammatory responses in primary human neutrophils. J Innate Immun. (2017) 9:375-386. doi: $10.1159 / 000455969$

78. Baeke F, Korf H, Overbergh L, van Etten E, Verstuyf A, Gysemans C, et al. Human $\mathrm{T}$ lymphocytes are direct targets of 1,25-dihydroxyvitamin D3 in the immune system. J Steroid Biochem Mol Biol. (2010) 121:221-7. doi: 10.1016/j.jsbmb.2010.03.037

79. Chen S, Sims GP, Chen XX, Gu YY, Chen S, Lipsky PE. Modulatory effects of 1,25-Dihydroxyvitamin $\mathrm{D}^{3}$ on human B cell differentiation. J Immunol. (2007) 179:1634-47. doi: 10.4049/jimmunol.179.3.1634

80. Thomas BJ, Kan-o K, Loveland KL, Elias JA, Bardin PG. In the shadow of fibrosis: innate immune suppression mediated by transforming growth factor- $\beta$. Am. J. Resp. Cell Mol. Biol. (2016) 55:759-66. doi: 10.1165/rcmb.2016-0248PS

81. Barnes PJ. Targeting cytokines to treat asthma and chronic obstructive pulmonary disease. Nat Rev Immunol. (2018) 18:454-66. doi: 10.1038/s41577-018-0006-6

82. Wedzicha JA, Seemungal TAR. COPD exacerbations: defining their cause and prevention. Lancet. (2007) 370:786-96. doi: 10.1016/S0140-6736(07)61382-8

83. Loxham M, Davies DE. Phenotypic and genetic aspects of epithelial barrier function in asthmatic patients. J Allergy Clin Immunol. (2017) 139:1736-51. doi: 10.1016/j.jaci.2017.04.005

84. Skolnik K, Quon BS. Recent advances in the understanding and management of cystic fibrosis pulmonary exacerbations. F1000Res. (2018) 7:F1000 Faculty Rev-575. doi: 10.12688/f1000research.13926.1

85. Schrumpf JA, van Sterkenburg MA, Verhoosel RM, Zuyderduyn S, Hiemstra PS. Interleukin 13 exposure enhances vitamin D-mediated expression of the human cathelicidin antimicrobial peptide 18/LL-37 in bronchial epithelial cells. Infect Immun. (2012) 80:4485-94. doi: 10.1128/IAI.06224-11

86. Liu MC, Xiao HQ, Brown AJ, Ritter CS, Schroeder J. Association of vitamin $\mathrm{D}$ and antimicrobial peptide production during late-phase allergic responses in the lung. Clin Exp Allergy. (2012) 42:383-91. doi: 10.1111/j.1365-2222.2011.03879.x

87. Barrea L, Savastano S, Di Somma C, Savanelli MC, Nappi F, Albanese L, et al. Low serum vitamin D-status, air pollution and obesity: a dangerous liaison. Rev Endocr Metab Disord. (2017) 18:207-14. doi: 10.1007/s11154-016-9388-6

88. Tzilas V, Bouros E, Barbayianni I, Karampitsakos T, Kourtidou S, Ntassiou $\mathrm{M}$, et al. Vitamin D prevents experimental lung fibrosis and predicts survival in patients with idiopathic pulmonary fibrosis. Pulm Pharmacol Ther. (2019) 55:17-24. doi: 10.1016/j.pupt.2019.01.003

89. Schlosser RJ, Carroll WW, Soler ZM, Pasquini WN, Mulligan JK. Reduced sinonasal levels of 1alpha-hydroxylase are associated with worse quality of 
life in chronic rhinosinusitis with nasal polyps. Int Forum Allergy Rhinol. (2016) 6:58-65. doi: 10.1002/alr.21576

90. Souberbielle JC, Body JJ, Lappe JM, Plebani M, Shoenfeld Y, Wang TJ, et al. Vitamin D and musculoskeletal health, cardiovascular disease, autoimmunity and cancer: recommendations for clinical practice. Autoimmun Rev. (2010) 9:709-15. doi: 10.1016/j.autrev.2010.06.009

91. DeLuca GC, Kimball SM, Kolasinski J, Ramagopalan SV, Ebers GC. Review: The role of vitamin D in nervous system health and disease. Neuropathol Appl Neurobiol. (2013) 39:458-84. doi: 10.1111/nan.12020

92. Dankers W, Colin EM, van Hamburg JP, Lubberts E. Vitamin D in autoimmunity: molecular mechanisms and therapeutic potential. Front Immunol. (2017) 7:697. doi: 10.3389/fimmu.2016.00697

93. Berridge MJ. Vitamin D cell signalling in health and disease. Biochem Biophys Res Commun. (2015) 460:53-71. doi: 10.1016/j.bbrc.2015.01.008

94. Aghapour M, Raee P, Moghaddam SJ, Hiemstra PS, Heijink IH. Airway epithelial barrier dysfunction in chronic obstructive pulmonary disease: role of cigarette smoke exposure. Am J RespirCell Mol Biol. (2018) 58:157-69. doi: $10.1165 / \mathrm{rcmb} .2017-0200 \mathrm{TR}$

95. Zhang R, Zhao H, Dong H, Zou F, Cai S. 1 $\alpha, 25$-Dihydroxyvitamin D3 counteracts the effects of cigarette smoke in airway epithelial cells. Cell Immunol. (2015) 295:137-43. doi: 10.1016/j.cellimm.2015.03.004

96. Shi YY, Liu TJ, Fu JH, Xu W, Wu LL, Hou AN, et al. Vitamin D/VDR signaling attenuates lipopolysaccharide-induced acute lung injury by maintaining the integrity of the pulmonary epithelial barrier. Mol Med Rep. (2016) 13:1186-94. doi: 10.3892/mmr.2015.4685

97. Gorman S, Buckley AG, Ling K-M, Berry LJ, Fear VS, Stick SM, et al. Vitamin D supplementation of initially vitamin D-deficient mice diminishes lung inflammation with limited effects on pulmonary epithelial integrity. Physiol Rep. (2017) 5:e13371. doi: 10.14814/phy2.13371

98. Luissint AC, Parkos CA, Nusrat A. Inflammation and the intestinal barrier: leukocyte-epithelial cell interactions, cell junction remodeling, mucosal repair. Gastroenterology. (2016) 151:616-32. doi: 10.1053/j.gastro.2016.07.008

99. Pezzulo AA, Tang XX, Hoegger MJ, Abou Alaiwa MH, Ramachandran $\mathrm{S}$, Moninger TO, et al. Reduced airway surface $\mathrm{pH}$ impairs bacterial killing in the porcine cystic fibrosis lung. Nature. (2012) 487:109-13. doi: 10.1038/nature11130

100. Rab A, Rowe SM, Raju SV, Bebok Z, Matalon S, Collawn JF. Cigarette smoke and CFTR: implications in the pathogenesis of COPD. Am J Physiol Lung Cell Mol Physiol. (2013) 305:L530-41. doi: 10.1152/ajplung.000 39.2013

101. Lamouille S, Xu J, Derynck R. Molecular mechanisms of epithelialmesenchymal transition. Nat Rev Mol Cell Biol. (2014) 15:178-96. doi: $10.1038 / \mathrm{nrm} 3758$

102. Milara J, Peiró T, Serrano A, Cortijo J. Epithelial to mesenchymal transition is increased in patients with COPD and induced by cigarette smoke. Thorax. (2013) 68:410-20. doi: 10.1136/thoraxjnl-2012-201761

103. Ricca C, Aillon A, Viano M, Bergandi L, Aldieri E, Silvagno F. Vitamin D inhibits the epithelial-mesenchymal transition by a negative feedback regulation of TGF- $\beta$ activity. J Steroid Biochem Mol Biol. (2018) doi: 10.1016/j.jsbmb.2018.11.006

104. Jiang F, Yang Y, Xue L, Li B, Zhang Z. 1 $\alpha, 25$-dihydroxyvitamin D3 attenuates TGF- $\beta$-induced pro-fibrotic effects in human lung epithelial cells through inhibition of epithelial-mesenchymal transition. Nutrients. (2017) 9:980. doi: 10.3390/nu9090980

105. Tan ZX, Chen YH, Xu S, Qin HY, Zhang C, Zhao H, et al. Calcitriol inhibits bleomycin-induced early pulmonary inflammatory response and epithelial-mesenchymal transition in mice. Toxicol Lett. (2016) 240:161-71. doi: 10.1016/j.toxlet.2015.10.022

106. Fischer KD, Hall SC, Agrawal DK. Vitamin D Supplementation Reduces Induction of Epithelial-Mesenchymal transition in allergen sensitized and challenged mice. PLoS ONE. (2016) 11:e0149180. doi: 10.1371/journal.pone.0149180

107. Hancock REW, Haney EF, Gill EE. The immunology of host defence peptides: beyond antimicrobial activity. Nat Rev Immunol. (2016) 16:321334. doi: $10.1038 /$ nri.2016.29

108. Wang TT, Nestel FP, Bourdeau V, Nagai Y, Wang Q, Liao J, et al. Cutting edge: 1,25-Dihydroxyvitamin D3 is a direct inducer of antimicrobial peptide gene expression. J Immunol. (2004) 173:2909-12. doi: 10.4049/jimmunol.173.5.2909

109. Huang FC. The differential effects of 1,25-dihydroxyvitamin D3 on Salmonella-induced interleukin- 8 and human beta-defensin-2 in intestinal epithelial cells. Clin Exp Immunol. (2016) 185:98-106. doi: 10.1111/cei.12792

110. Wang TT, Dabbas B, Laperriere D, Bitton AJ, Soualhine H, Tavera-Mendoza LE, et al. Direct and indirect induction by 1,25-dihydroxyvitamin D3 of the NOD2/CARD15-Defensin $\beta 2$ innate immune pathway defective in crohn disease. J Biol Chem. (2010) 285:2227-31. doi: 10.1074/jbc.C109.071225

111. Gonzalez-Curiel I, Trujillo V, Montoya-Rosales A, Rincon K, RivasCalderon B, deHaro-Acosta J, et al. 1,25-dihydroxyvitamin D3 induces LL-37 and HBD-2 production in keratinocytes from diabetic foot ulcers promoting wound healing: an in vitro model. PLoS ONE. (2014) 9:e111355. doi: 10.1371/journal.pone.0111355

112. Dai X, Sayama K, Tohyama M, Shirakata Y, Hanakawa Y, Tokumaru S, et al. $\operatorname{PPAR} \gamma$ mediates innate immunity by regulating the $1 \alpha, 25$-dihydroxyvitamin D3 induced hBD-3 and cathelicidin in human keratinocytes. J Dermatol Sci. (2010) 60:179-86. doi: 10.1016/j.jdermsci.2010.09.008

113. Hou W, Hu S, Li C, Ma H, Wang Q, Meng G, et al. Cigarette smoke induced lung barrier dysfunction, EMT, and tissue remodeling: a possible link between COPD and lung cancer. Biomed Res Int. (2019) 2019:2025636. doi: $10.1155 / 2019 / 2025636$

114. Ito JT, Lourenço JD, Righetti RF, I.Tibério FLC, Prado CM, F.D.Lopes TQS. Extracellular matrix component remodeling in respiratory diseases: what has been found in clinical and experimental studies? Cells. (2019) 8:342. doi: 10.3390/cells8040342

115. Shimshoni E, Yablecovitch D, Baram L, Dotan I, Sagi I. ECM remodelling in IBD: innocent bystander or partner in crime? The emerging role of extracellular molecular events in sustaining intestinal inflammation. Gut. (2015) 64:367-72. doi: 10.1136/gutjnl-2014-308048

116. Hansdottir S, Monick MM, Lovan N, Powers L, Gerke A, Hunninghake GW. Vitamin D decreases respiratory syncytial virus induction of NF-kappaB-linked chemokines and cytokines in airway epithelium while maintaining the antiviral state. J Immunol. (2010) 184:965-74. doi: 10.4049/jimmunol.0902840

117. Pfeffer PE, Chen YH, Woszczek G, Matthews NC, Chevretton E, Gupta A, et al. Vitamin D enhances production of soluble ST2, inhibiting the action of IL-33. J Allergy Clin Immunol. (2015) 135:824-7.e3. doi: 10.1016/j.jaci.2014.09.044

118. Vanherwegen AS, Gysemans C, Mathieu C. Regulation of immune function by vitamin D and Its use in diseases of immunity. Endocrinol Metab Clin North Am. (2017) 46:1061-94. doi: 10.1016/j.ecl.2017.07.010

119. Pfeffer PE, Hawrylowicz CM. Vitamin D in asthma: mechanisms of action and considerations for clinical trials. Chest. (2018) 153:1229-39. doi: 10.1016/j.chest.2017.09.005

120. Mercado N, Ito K, Barnes PJ. Accelerated ageing of the lung in COPD: new concepts. Thorax. (2015) 70:482-9. doi: 10.1136/thoraxjnl-2014-206084

121. Haussler MR, Whitfield GK, Kaneko I, Haussler CA, Hsieh D, Hsieh JC, et al. Molecular mechanisms of vitamin D action. Calcified Tissue Int. (2013) 92:77-98. doi: 10.1007/s00223-012-9619-0

122. Torres PU, Prié D, Molina-Blétry V, Beck L, Silve C, Friedlander G. Klotho: an antiaging protein involved in mineral and vitamin D metabolism. Kidney Int. (2007) 71:730-7. doi: 10.1038/sj.ki.5002163

123. Krick S, Grabner A, Baumlin N, Yanucil C, Helton S, Grosche A, et al. Fibroblast growth factor 23 and Klotho contribute to airway inflammation. Eur Respir J. (2018) 52:1800236. doi: 10.1183/13993003.00236-2018

124. Gao W, Yuan C, Zhang J, Li L, Yu L, Wiegman CH, et al. Klotho expression is reduced in COPD airway epithelial cells: effects on inflammation and oxidant injury. Clin Sci. (2015) 129:1011-23. doi: 10.1042/CS20150273

125. Li YC, Chen Y, Du J. Critical roles of intestinal epithelial vitamin D receptor signaling in controlling gut mucosal inflammation. J Steroid Biochem Mol Biol. (2015) 148:179-83. doi: 10.1016/j.jsbmb.2015.01.011

126. Lu R, Zhang YG, Xia Y, Sun J. Imbalance of autophagy and apoptosis in intestinal epithelium lacking the vitamin D receptor. FASEB J. (2019) 33:11845-856. doi: 10.1096/fj.201900727R

127. Racanelli AC, Kikkers SA, Choi AMK, Cloonan SM. Autophagy and inflammation in chronic respiratory disease. Autophagy. (2018) 14:221-32. doi: $10.1080 / 15548627.2017 .1389823$ 
128. Malvin NP, Kern JT, Liu TC, Brody SL, Stappenbeck TS. Autophagy proteins are required for club cell structure and function in airways. Am J Physiol Lung Cell Mol Physiol. (2019) 317:L259-L70. doi: 10.1152/ajplung.00394.2018

129. Barnes PJ. Corticosteroid resistance in patients with asthma and chronic obstructive pulmonary disease. J Allergy Clin Immunol. (2013) 131:636-45. doi: 10.1016/j.jaci.2012.12.1564

130. Xystrakis E, Kusumakar S, Boswell S, Peek E, Urry Z, Richards DF, et al. Reversing the defective induction of IL-10-secreting regulatory $\mathrm{T}$ cells in glucocorticoid-resistant asthma patients. J Clin Invest. (2006) 116:146-55. doi: $10.1172 /$ JCI21759

131. Sutherland ER, Goleva E, Jackson LP, Stevens AD, Leung DYM. Vitamin D levels, lung function, and steroid response in adult asthma. Am J RespirCrit Care Med. (2010) 181:699-704. doi: 10.1164/rccm.200911-1710OC

132. Lan N, Luo G, Yang X, Cheng Y, Zhang Y, Wang X, et al. 25Hydroxyvitamin D3-deficiency enhances oxidative stress and corticosteroid resistance in severe asthma exacerbation. PLoS ONE. (2014) 9:e111599. doi: 10.1371/journal.pone.0111599

133. Konya V, Czarnewski P, Forkel M, Rao A, Kokkinou E, Villablanca EJ, et al. Vitamin D downregulates the IL-23 receptor pathway in human mucosal group 3 innate lymphoid cells. J Allergy Clin Immunol. (2018) 141:279-92. doi: 10.1016/j.jaci.2017.01.045

134. Mann EH, Ho TR, Pfeffer PE, Matthews NC, Chevretton E, Mudway I, et al. Vitamin D counteracts an IL-23-dependent IL-17A(+)IFN- $\gamma(+)$ response driven by urban particulate matter. Am J Respir Cell Mol Biol. (2017) 57:355-66. doi: 10.1165/rcmb.2016-0409OC

135. Fawaz L, Mrad MF, Kazan JM, Sayegh S, Akika R, Khoury SJ. Comparative effect of $25(\mathrm{OH}) \mathrm{D} 3$ and $1,25(\mathrm{OH}) 2 \mathrm{D} 3$ on Th17 cell differentiation. Clin Immunol. (2016) 166-7:59-71. doi: 10.1016/j.clim.201 6.02 .011

136. Nanzer AM, Chambers ES, Ryanna K, Richards DF, Black C, Timms PM, et al. Enhanced production of IL-17A in patients with severe asthma is inhibited by $1 \alpha, 25$-dihydroxyvitamin D3 in a glucocorticoidindependent fashion. J Allergy Clin Immunol. (2013) 132:297-304.e3. doi: 10.1016/j.jaci.2013.03.037

137. Dhawan P, Christakos S. Novel regulation of 25-hydroxyvitamin D3 24-hydroxylase $(24(\mathrm{OH})$ ase $)$ transcription by glucocorticoids: cooperative effects of the glucocorticoid receptor, C/EBP $\beta$, and the Vitamin D receptor in 24(OH)ase transcription. J Cell Biochem. (2010) 110:1314-23. doi: $10.1002 /$ jcb. 22645

138. Donaldson GC, Seemungal TAR, Bhowmik A, Wedzicha JA. Relationship between exacerbation frequency and lung function decline in chronic obstructive pulmonary disease. Thorax. (2002) 57:847-52. doi: $10.1136 /$ thorax. 57.10 .847

139. Decramer M, Janssens W, Miravitlles M. Chronic obstructive pulmonary disease. Lancet. (2012) 379:1341-51. doi: 10.1016/S0140-6736(11)60968-9

140. Leung JM, Tiew PY, Mac Aogáin M, Budden KF, Yong VFL, Thomas SS, et al. The role of acute and chronic respiratory colonization and infections in the pathogenesis of COPD. Respirology. (2017) 22:634-50. doi: $10.1111 /$ resp. 13032

141. Wang Z, Bafadhel M, Haldar K, Spivak A, Mayhew D, Miller $\mathrm{BE}$, et al. Lung microbiome dynamics in COPD exacerbations. Eur Respir J. (2016) 47:1082-92. doi: $10.1183 / 13993003.014$ 06-2015

142. Bolcas PE, Brandt EB, Zhang Z, Myers JM, Ruff BP, Hershey GK. Vitamin D supplementation attenuates asthma development following traffic-related particulate matter exposure. J Allergy Clin Immunol. (2019) 143:386-94.e3. doi: 10.1016/j.jaci.2018.04.042

143. Wang H, Anthony D, Selemidis S, Vlahos R, Bozinovski S. Resolving viralinduced secondary bacterial infection in COPD: a concise review. Front Immunol. (2018) 9:2345. doi: 10.3389/fimmu.2018.02345

144. Stolz D, Papakonstantinou E, Grize L, Schilter D, Strobel W, Louis R, et al. Time-course of upper respiratory tract viral infection and COPD exacerbation. Eur Respir J. (2019) 54:1900407. doi: 10.1183/13993003.00407-2019

145. Schogler A, Muster RJ, Kieninger E, Casaulta C, Tapparel C, Jung A, et al. Vitamin D represses rhinovirus replication in cystic fibrosis cells by inducing LL-37. Eur Respir J. (2016) 47:520-30. doi: 10.1183/13993003.0066 5-2015
146. Sousa FH, Casanova V, Findlay F, Stevens C, Svoboda P, Pohl J, et al. Cathelicidins display conserved direct antiviral activity towards rhinovirus. Peptides. (2017) 95:76-83. doi: 10.1016/j.peptides.2017.07.013

147. Brockman-Schneider RA, Pickles RJ, Gern JE. Effects of vitamin D on airway epithelial cell morphology and rhinovirus replication. PLoS ONE. (2014) 9:e86755. doi: 10.1371/journal.pone.0086755

148. Gui B, Chen Q, Hu C, Zhu C, He G. Effects of calcitriol (1, 25-dihydroxyvitamin D3) on the inflammatory response induced by H9N2 influenza virus infection in human lung A549 epithelial cells and in mice. Virol J. (2017) 14:10. doi: 10.1186/s12985-017-0683-y

149. Khare D, Godbole NM, Pawar SD, Mohan V, Pandey G, Gupta S, et al. Calcitriol $[1,25[\mathrm{OH}] 2 \mathrm{D} 3]$ pre- and post-treatment suppresses inflammatory response to influenza A (H1N1) infection in human lung A549 epithelial cells. Eur J Nutr. (2013) 52:1405-15. doi: 10.1007/s00394-012-0449-7

150. Sethi S, Murphy TF. Infection in the pathogenesis and course of chronic obstructive pulmonary disease. N Engl J Med. (2008) 359:2355-65. doi: 10.1056/NEJMra0800353

151. Sethi S, Evans N, Grant BJB, Murphy TF. New strains of bacteria and exacerbations of chronic obstructive pulmonary disease. N Eng J Med. (2002) 347:465-71. doi: 10.1056/NEJMoa012561

152. Wilkinson TMA, Aris E, Bourne S, Clarke SC, Peeters M, Pascal TG, et al. A prospective, observational cohort study of the seasonal dynamics of airway pathogens in the aetiology of exacerbations in COPD. Thorax. (2017) 72:919-27. doi: 10.1136/thoraxjnl-2016-209023

153. Yim S, Dhawan P, Ragunath C, Christakos S, Diamond G. Induction of cathelicidin in normal and CF bronchial epithelial cells by 1,25-dihydroxyvitamin $\mathrm{D}(3)$. J Cystic Fibrosis. (2007) 6:403-10. doi: $10.1016 /$ j.jcf.2007.03.003

154. Dimitrov V, White JH. Species-specific regulation of innate immunity by vitamin D signaling. J Steroid Biochem Mol Biol. (2016) 164:246-53. doi: $10.1016 /$ j.jsbmb.2015.09.016

155. Gombart AF, Borregaard N, Koeffler HP. Human cathelicidin antimicrobial peptide (CAMP) gene is a direct target of the vitamin D receptor and is strongly up-regulated in myeloid cells by 1,25 -dihydroxyvitamin D3. FASEB J. (2005) 19:1067-77. doi: 10.1096/fj.04-3284com

156. Niederstrasser J, Herr C, Wolf L, Lehr CM, Beisswenger C, Bals R. Vitamin $\mathrm{D}$ deficiency does not result in a breach of host defense in murine models of pneumonia. Infect Immun. (2016) 84:3097-104. doi: 10.1128/IAI.00282-16

157. Lowry MB, Guo C, Zhang Y, Fantacone ML, Logan IE, Campbell Y, et al. A mouse model for vitamin D-induced human cathelicidin antimicrobial peptide gene expression. J Steroid Biochem Mol Biol. (2019) 198:105552. doi: $10.1016 /$ j.jsbmb.2019.105552

158. Zuo W-L, Shenoy SA, Li S, O'Beirne SL, Strulovici-Barel Y, Leopold PL, et al. Ontogeny and biology of human small airway epithelial club cells. Am J Respir Crit Care Med. (2018) 198:1375-88. doi: 10.1164/rccm.201710-2107OC

159. Clark A, Mach N. Role of vitamin D in the hygiene hypothesis: the interplay between vitamin $\mathrm{d}$, vitamin $\mathrm{d}$ receptors, gut microbiota, immune response. Front Immunol. (2016) 7:627. doi: 10.3389/fimmu.2016.00627

160. Salzman NH. Paneth cell defensins and the regulation of the microbiome: détente at mucosal surfaces. Gut Microbes. (2010) 1:401-6. doi: 10.4161/gmic.1.6.14076

161. Cullen TW, Schofield WB, Barry NA, Putnam EE, Rundell EA, Trent MS, et al. Gut microbiota. Antimicrobial peptide resistance mediates resilience of prominent gut commensals during inflammation. Science. (2015) 347:170-5. doi: $10.1126 /$ science. 1260580

162. Budden KF, Gellatly SL, Wood DLA, Cooper MA, Morrison M, Hugenholtz $\mathrm{P}$, et al. Emerging pathogenic links between microbiota and the gut-lung axis. Nat Rev Microbiol. (2016) 15:55. doi: 10.1038/nrmicro.2016.142

163. Dang AT, Marsland BJ. Microbes, metabolites, and the gut-lung axis. Mucosal Immunol. (2019) 12:843-850. doi: 10.1038/s41385-019-0160-6

164. Waterhouse M, Hope B, Krause L, Morrison M, Protani MM, Zakrzewski $\mathrm{M}$, et al. Vitamin D and the gut microbiome: a systematic review of in vivo studies. Eur J Nutr. (2019) 58:2895-910. doi: 10.1007/s00394-018-1842-7

165. Talsness CE, Penders J, E.Jansen HJM, Damoiseaux J, Thijs C, Mommers M. Influence of vitamin D on key bacterial taxa in infant microbiota in the KOALA birth cohort study. PLoS ONE. (2017) 12:e0188011. doi: 10.1371/journal.pone.0188011 
166. Schaffler H, Herlemann DP, Klinitzke P, Berlin P, Kreikemeyer B, Jaster R, et al. Vitamin D administration leads to a shift of the intestinal bacterial composition in crohn's disease patients, but not in healthy controls. J Dig Dis. (2018) 19:225-34. doi: 10.1111/1751-2980.12591

167. Sullivan A, Hunt E, MacSharry J, Murphy DM. 'The microbiome and the pathophysiology of asthma'. Respir Res. (2016) 17:163. doi: 10.1186/s12931-016-0479-4

168. Mammen MJ, Sethi S. COPD and the microbiome. Respirology. (2016) 21:590-9. doi: $10.1111 /$ resp. 12732

169. Toivonen L, Hasegawa K, Ajami NJ, Celedon JC, Mansbach JM, Petrosino JF, et al. circulating 25-hydroxyvitamin D, nasopharyngeal microbiota, bronchiolitis severity. Pediatr Allergy Immunol. (2018) 29:87780. doi: 10.1111/pai.12977

170. Kanhere M, He J, Chassaing B, Ziegler TR, Alvarez JA, Ivie EA, et al. Bolus weekly vitamin D3 supplementation impacts gut and airway microbiota in adults with cystic fibrosis: a double-blind, randomized, placebo-controlled clinical trial. J Clin Endocrinol Metab. (2018) 103:564-74. doi: 10.1210/jc.2017-01983

171. Zendedel A, Gholami M, Anbari K, Ghanadi K, Bachari EC, Azargon A. Effects of vitamin D Intake on FEV1 and COPD exacerbation: a randomized clinical trial study. Glob J Health Sci. (2015) 7:243-8. doi: 10.5539/gjhs.v7n4p243

172. Khan DM, Ullah A, Randhawa FA, Iqtadar S, Butt NF, Waheed K. Role of vitamin $\mathrm{D}$ in reducing number of acute exacerbations in chronic obstructive pulmonary disease (COPD) patients. J Med Sci. (2017) 33:610-4. doi: $10.12669 /$ pjms.333.12397

173. Lehouck A, Mathieu C, Carremans C, Baeke F, Verhaegen J, Van Eldere J, et al. High doses of vitamin D to reduce exacerbations in chronic obstructive pulmonary disease: a randomized trial. Ann Intern Med. (2012) 156:105-14. doi: 10.7326/0003-4819-156-2-201201170-00004

174. Martineau AR, James WY, Hooper RL, Barnes NC, Jolliffe DA, Greiller CL, et al. Vitamin D3 supplementation in patients with chronic obstructive pulmonary disease (ViDiCO): a multicentre, double-blind, randomised controlled trial. Lancet Respir Med. (2015) 3:120-30. doi: 10.1016/S2213-2600(14)70255-3

175. Jolliffe DA, Greenberg L, Hooper RL, Mathyssen C, Rafiq R, de Jongh RT, et al. Vitamin D to prevent exacerbations of COPD: systematic review and meta-analysis of individual participant data from randomised controlled trials. Thorax. (2019) 74:337-45. doi: 10.1136/thoraxjnl-2018-212092

176. Rafiq R, Aleva FE, Schrumpf JA, Heijdra YF, Taube C, Daniels JMA, et al. Prevention of exacerbations in patients with COPD and vitamin D deficiency through vitamin D supplementation (PRECOVID): a study protocol. BMC Pulm Med. (2015) 15:106. doi: 10.1186/s12890-015-0101-4

177. Martineau AR, Jolliffe DA, Hooper RL, Greenberg L, Aloia JF, Bergman $\mathrm{P}$, et al. Vitamin D supplementation to prevent acute respiratory tract infections: systematic review and meta-analysis of individual participant data. BMJ. (2017) 356:i6583. doi: 10.1136/bmj.i6583

178. Wang M, Liu M, Wang C, Xiao Y, An T, Zou M, et al. Association between vitamin D status and asthma control: a meta-analysis of randomized trials. Respir Med. (2019) 150:85-94. doi: 10.1016/j.rmed.2019.02.016

179. Ramos-Martínez E, López-Vancell MR, Fernández de Córdova-Aguirre JC, Rojas-Serrano J, Chavarría A, Velasco-Medina A, et al. Reduction of respiratory infections in asthma patients supplemented with vitamin $\mathrm{D}$ is related to increased serum IL-10 and IFN $\gamma$ levels and cathelicidin expression. Cytokine. (2018) 108:239-46. doi: 10.1016/j.cyto.2018.01.001

180. Wani WA, Nazir M, Bhat JI, E.-u.-h. Malik, Ahmad QI, Charoo $\mathrm{BA}$, et al. Vitamin D status correlates with the markers of cystic fibrosis-related pulmonary disease. Pediatr Neonatol. (2019) 60:210-215. doi: 10.1016/j.pedneo.2018.07.001

181. Tangpricha V, Lukemire J, Chen Y, Binongo JNG, Judd SE, Michalski ES, et al. Vitamin D for the immune system in cystic fibrosis (DISC): a double-blind, multicenter, randomized, placebo-controlled clinical trial. Am J Clin Nutr. (2019) 109:544-53. doi: 10.1093/ajcn/nqy291

182. Luo W, Hershberger PA, Trump DL, Johnson CS. 24-Hydroxylase in cancer: impact on vitamin D-based anticancer therapeutics. $J$ Steroid Biochem Mol Biol. (2013) 136:252-7. doi: 10.1016/j.jsbmb.201 2.09 .031

183. Amatngalim GD, Broekman W, Daniel NM, van der Vlugt LEPM, van Schadewijk A, Taube C, et al. Cigarette smoke modulates repair and innate immunity following injury to airway epithelial cells. PLoS ONE. (2016) 11:e0166255. doi: 10.1371/journal.pone.0166255

184. Toshiyuki S, Kaori Y, Atsushi K, Keiko Y, Tai CC. CYP24A1 as a potential target for cancer therapy. Anti-Cancer Agents Med Chem. (2014) 14:97-108. doi: 10.2174/18715206113139990307

185. Lachapelle P, Li M, Douglass J, Stewart A. Safer approaches to therapeutic modulation of TGF-beta signaling for respiratory disease. Pharmacol Ther. (2018) 187:98-113. doi: 10.1016/j.pharmthera.201 8.02.010

Conflict of Interest: The authors declare that the research was conducted in the absence of any commercial or financial relationships that could be construed as a potential conflict of interest.

Copyright (๑) 2020 Schrumpf, van der Does and Hiemstra. This is an open-access article distributed under the terms of the Creative Commons Attribution License (CC $B Y)$. The use, distribution or reproduction in other forums is permitted, provided the original author(s) and the copyright owner(s) are credited and that the original publication in this journal is cited, in accordance with accepted academic practice. No use, distribution or reproduction is permitted which does not comply with these terms. 